\title{
Energy Return on Investment for Algal Biofuel Production Coupled with Wastewater Treatment
}

\author{
Colin M. Beal ${ }^{1,2 *}$, Ashlynn S. Stillwell ${ }^{3}$, Carey W. King ${ }^{4,5}$, Stuart M. Cohen ${ }^{2}$, Halil Berberoglu², \\ Rajendra P. Bhattarai ${ }^{6}$, Rhykka L. Connelly ${ }^{1}$, Michael E. Webber ${ }^{2,4}$, Robert E. Hebner ${ }^{1,2}$
}

\begin{abstract}
This study presents a second-order energy return on investment analysis to evaluate the mutual benefits of combining an advanced wastewater treatment plant (WWTP) (with biological nutrient removal) with algal biofuel production. With conventional, independently operated systems, algae production requires significant material inputs, which require energy directly and indirectly, and the WWTP requires significant energy inputs for treatment of the waste streams. The second-order energy return on investment values for independent operation of the WWTP and the algal biofuels production facility were determined to be 0.37 and 0.42 , respectively. By combining the two, energy inputs can be reduced significantly. Consequently, the integrated system can outperform the isolated system, yielding a second-order energy return on investment of 1.44. Combining these systems transforms two energy sinks to a collective (second-order) energy source. However, these results do not include capital, labor, and other required expenses, suggesting that profitable deployment will be challenging. Water Environ. Res., 84, 692 (2012).
\end{abstract}

KEYWORDS: wastewater treatment, algae, biofuel, algal biofuel production, biological nutrient removal, energy return on investment, energy balance, synergy.

doi:10.2175/106143012X13378023685718

\section{Introduction}

Although algal biofuels possess many potential advantages, such as the ability to produce petroleum fuel substitutes without the need for fresh water or arable land (Schenk et al., 2008; Sheehan et al., 1998; Wijffels and Barbosa, 2010), profitable production has yet to be realized. Previous studies have characterized the constraints on algal biofuel production technologies. These constraints include energy and financial

\footnotetext{
${ }^{1}$ The Center for Electromechanics, University of Texas at Austin, Austin, 1 University Station R7000, Austin, TX 78712.

${ }^{2}$ Department of Mechanical Engineering, University of Texas at Austin.

${ }^{3}$ Department of Civil, Architectural, and Environmental Engineering, University of Texas at Austin.

${ }^{4}$ Center for International Energy and Environmental Policy, University of Texas at Austin.

${ }^{5}$ Jackson School of Geoscience, University of Texas at Austin.

${ }^{6}$ Austin Water Utility, Environmental and Regulatory Services Division, City of Austin, Austin, Texas.

* The Center for Electromechanics, University of Texas at Austin, Austin, 1 University Station R7000, Austin, TX 78712; e-mail: colinmbeal@gmail.com; Department of Mechanical Engineering, University of Texas at Austin.
}

return on investments less than 1 , higher water intensity than conventional fuels, and large resource requirements associated with large-scale biofuel production (particularly carbon, nitrogen, and phosphorus) (Batan et al., 2010; Beal, 2011; Beal et al., 2011a; Campbell et al., 2010; Clarens et al., 2010; Collet et al., 2011; Davis et al., 2011; Lardon et al., 2009; Pate et al., 2011). Based on these factors, it is advantageous for the algal biofuels industry to identify widely available resources with low cost and low-energy intensity for use in cultivating algae. Coupling wastewater treatment with high-rate algal cultivation has the potential to alleviate the aforementioned constraints (Christenson and Sims, 2011; Lundquist et al., 2010; Park and Craggs, 2011; Park et al., 2010; Pittman et al., 2011; Sturm and Lamer, 2011; Zhou et al., 2011).

The concept of coupling wastewater treatment with algal biofuel production has been evaluated in several previous studies. Clarens et al. (2010) reported that using partially treated wastewater can reduce the amount of energy embedded in nitrogen and phosphorus used for cultivating algae and reduce treatment costs for municipal wastewater facilities. Lundquist et al. (2011) presented a techno-economic analysis for five cases in which algal biofuels are produced in conjunction with wastewater treatment. That study predicted that even with revenue generated from wastewater treatment, oil prices need to approach $\$ 300 /$ bbl for economic algal biofuel production. Other analyses have presented techniques available for growing and harvesting algae using wastewater resources (Christenson and Sims, 2011; Park and Craggs, 2011; Park et al., 2010). Pittman et al. (2011) presented a review of algal cultivation studies using wastewater that highlights the potential advantages of coupling algal cultivation with wastewater treatment. Finally, a study by Sturm and Lamer (2011) demonstrates the feasibility of cultivating algae on wastewater effluent and presents a firstorder energy analysis for cultivation and harvesting. That study suggests that the direct energy produced from algal biofuels and the energy savings afforded by avoiding biological nutrient removal (BNR) can outweigh direct energy costs of growing and harvesting algae.

Each of these studies has indicated the potential advantages of coupling wastewater treatment with algal cultivation. This work extends these results by quantifying the energy return on investment (EROI) for a coupled wastewater treatment and algal biofuels production system by considering operation of the entire wastewater treatment system and the entire algal biofuels production pathway. That is, the authors hypothesize that modeling the integration of two net energy-consuming operations (i.e., a wastewater treatment facility and an algal biofuels 
production facility) will result in one net energy-positive facility (i.e., coupled wastewater treatment and algal biofuels production) attributed to synergistic benefits.

The EROI, which is calculated as the ratio between the energy produced and the energy consumed by an energy system, is a critical measure for evaluating the net energetic profitability of that system (Hall et al., 1984; King, 2010; Mulder and Hagens, 2009). As the EROI increases, the energetic profitability of that energy system also increases. For any feedstock (e.g., algae) or combination of feedstocks (e.g., algae and wastewater) to be a net energy source, the EROI to operate the entire associated production system(s) must be greater than 1. However, historically, the EROI of delivered energy carriers has been much greater than 1 and, therefore, practical deployment of an energy source typically requires an EROI much greater than 1 . For instance, the EROI has been used to characterize several conventional fuels; for example, for coal, oil and gas, and corn ethanol, the second-order EROI has been estimated to be $\sim 80$ (at the mine), $\sim 15$ (at the well), and $\sim 1$ (at the biorefinery), respectively (Cleveland, 2005; Farrell et al., 2006; King, 2010; Kubiszewski et al., 2010; Shapouri et al., 2002). Delivered gasoline (considering the entire supply chain) has had an overall EROI of 5 to 10 (Henshaw et al., 2011; King, 2010) (Figure 2).

Similarly, EROI is used in the present analysis to evaluate the potential feasibility of producing biofuels from a combined system of wastewater treatment and algal biomass production. However, the need to treat wastewater is not driven by energetic profitability, rather, by public health and environmental needs. While wastewater treatment systems can generate energy with certain configurations, the EROI for wastewater treatment is generally less than 1 (Stillwell et al., 2010). In contrast to existing conventional wastewater treatment systems, which simply consume energy to clean water, the integrated system cleans the water while also producing fuels as a byproduct, which might improve the energetic and financial balance of the entire system.

This study presents a calculation of the second-order energy return on investment ( $2^{\text {nd }} O E R O I$ ) for an idealized system that integrates wastewater treatment with algal biofuel production. The $2^{\text {nd }} O$ EROI considers the energy embedded in materials consumed, in addition to the actual energy production and consumption flows comprising the first-order EROI, making $2^{\text {nd }}$ $O E R O I$ a more holistic metric of system-wide sustainability (Mulder and Hagens, 2009). As an example, energy required for mixing an algal cultivation pond is included in both the firstand second-order EROI, while energy embedded in nitrogen fertilizer used for algal cultivation is only included in the secondorder EROI. Although it is possible to further broaden the system boundary to include additional business and engineering operations (Henshaw et al., 2011), the authors did not perform this task because of the immature state of algal fuel production.

The wastewater treatment system modeled in this analysis is an advanced wastewater treatment plant (WWTP) with BNR (Goldstein and Smith, 2002; Tchobanoglous et al., 2003), and the algal biofuels production system is based on growth and processing technologies that have been described previously (Beal, 2011; Beal et al., 2011a; Beal et al., 2011b). However, throughout the world, the equipment, processes, and methods used for both wastewater treatment and algal biofuel production vary widely (Amin, 2009; Beal et al., 2011b; Brennan and Owende, 2010; Goldstein and Smith, 2002; Huang et al., 2010; Tchobanoglous et al., 2003; Wiley et al., 2011). The EROI for any particular WWTP, algal biofuels production facility, or coupled WWTP and algal biofuels production facility depends on the specific technologies used at those locations. Moreover, system performance, energy production, and energy savings can also be affected by which wastewater stream is used (e.g., raw wastewater, primary effluent, secondary effluent, sludge effluent, etc.). Thus, when one considers implementing this type of system, it is important to evaluate site-specific conditions and determine the associated EROI for that specific location. This study provides a baseline example of the mutual benefits afforded by coupling algal biofuel production with wastewater treatment, outlines the important parameters to consider when determining the associated $2^{\text {nd }} O E R O I$ for such a combined system, and provides energy consumption and production data for the important processes. In addition, this study presents the $2^{\text {nd }} O$ EROI for an advanced WWTP with nutrient removal operating independently from algal biofuel production, which has not been reported previously.

\section{Methodology}

The wastewater treatment system and algal biofuel production pathway evaluated in this study are illustrated in Figure 1. The basic approach for this analysis is to identify how the wastewater treatment facility and algal biofuel production systems would operate independently, and then consider the net energy effect associated with coupling the algal biofuel production system with the wastewater treatment system (i.e., combined operation). Although wastewater treatment facilities and algal biofuel production are not often net energy positive independently (i.e., they do not have EROI values greater than 1), opportunities exist to integrate the two facilities such that synergistic benefits cause the EROI of the combined operations to be greater than 1. During independent operations, the two systems are completely disconnected, while, under combined operations, the algal biofuels production system receives primary effluent and carbon dioxide $\left(\mathrm{CO}_{2}\right)$ from the wastewater treatment facility. The wastewater treatment facility is modeled as an advanced wastewater treatment facility based on the descriptions provided by Tchobanoglous et al. (2003) and Goldstein and Smith (2002), with the addition of BNR. The inclusion of BNR in wastewater treatment is based on the expectation that increasingly strict effluent regulations will require most large WWTPs to implement nutrient removal in the near future. That is, the analysis of the present study is forward-looking in its broad applicability (Parker, 2011). In 1998, the U.S. Environmental Protection Agency published the National Strategy for the Development of Regional Nutrient Criteria (U.S. EPA, 1998) with the expectation that states adopt nutrient criteria by 2004 . Although many states were unable to meet the 2004 deadline, there has been progress in this area, and the expectation is that large plants will be required to implement nutrient removal soon. A scenario that omits BNR for wastewater treatment is also considered in the sensitivity analysis.

The algal biofuel production pathway is modeled as an idealized system that uses open ponds (Beal, 2011; Sheehan et al., 1998), processing technologies that have been developed at The University of Texas at Austin (i.e., harvesting, lysing, and separations) (Beal, 2011; Beal et al., 2011a; Choi, 2009; Connelly et al., In Preparation), and refining methods that have been described in the literature (Batan et al., 2010; Lardon et al., 


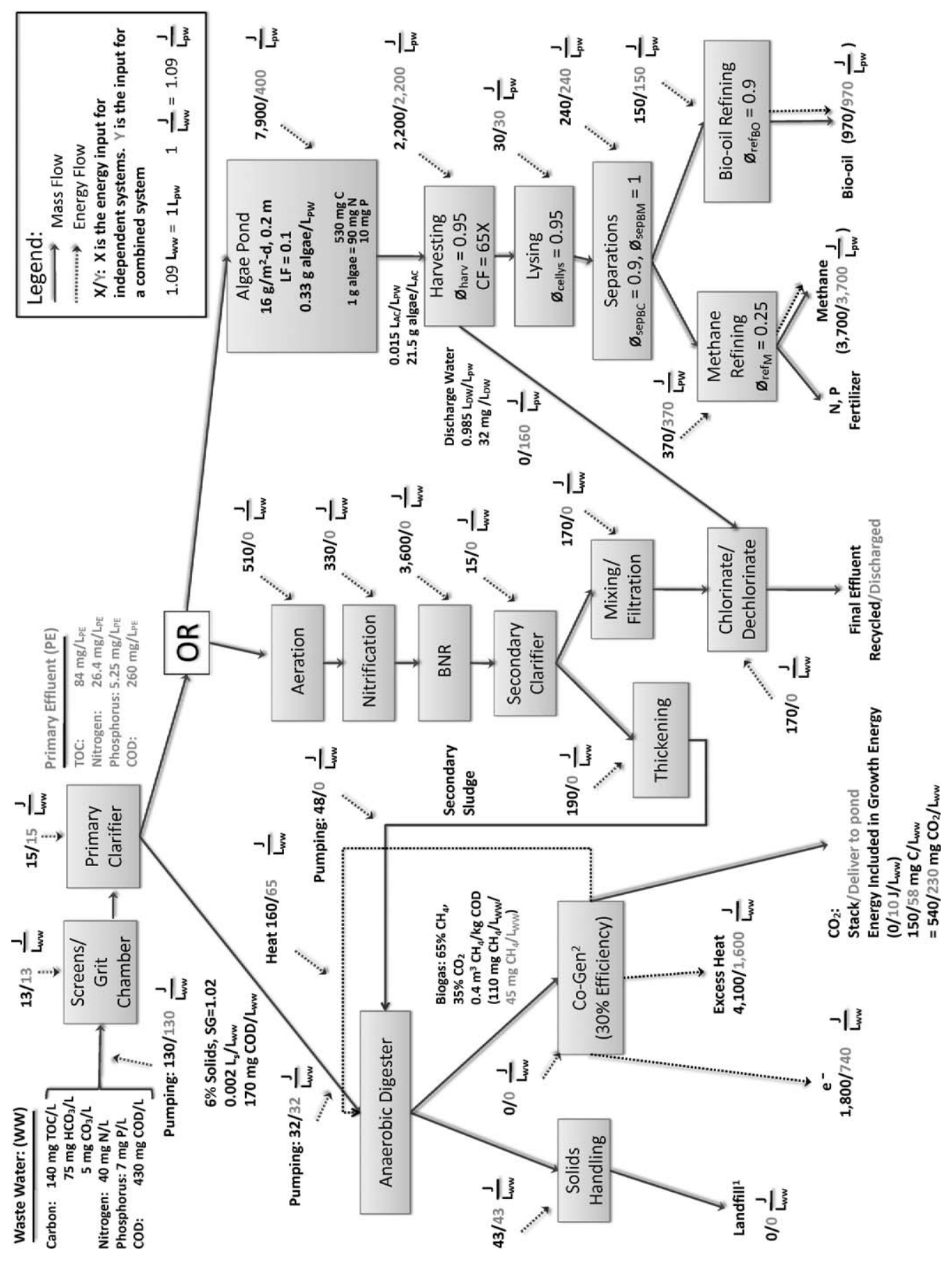

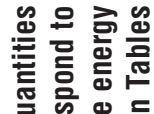

홍 혼 ᄈ્三

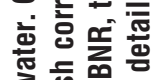

药

동흔 흔

造兽㤩

인잉ㅎㅀ

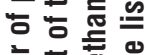

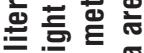

등 和

흥웧ㅎㅇ

웜 흠

沓

으 흘 혼

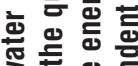

言 일

究空

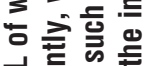

영 흘 吉

흥

흘 을 흥 흥

홓 트은

응

बे के गे

ธั口을

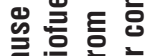

웜는

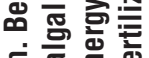

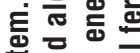

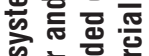

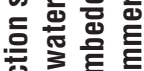

흘 흥

힌 可言..

舟卷

冚

을 突言

픔흠츰

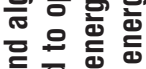

등ㅎㅀ

흥 항

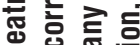

돈

帝

칭 홍 둥

홍 홍

恣豆

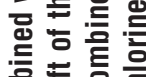

흘흐응 응

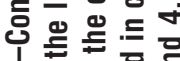

1 을

ब综

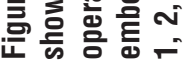




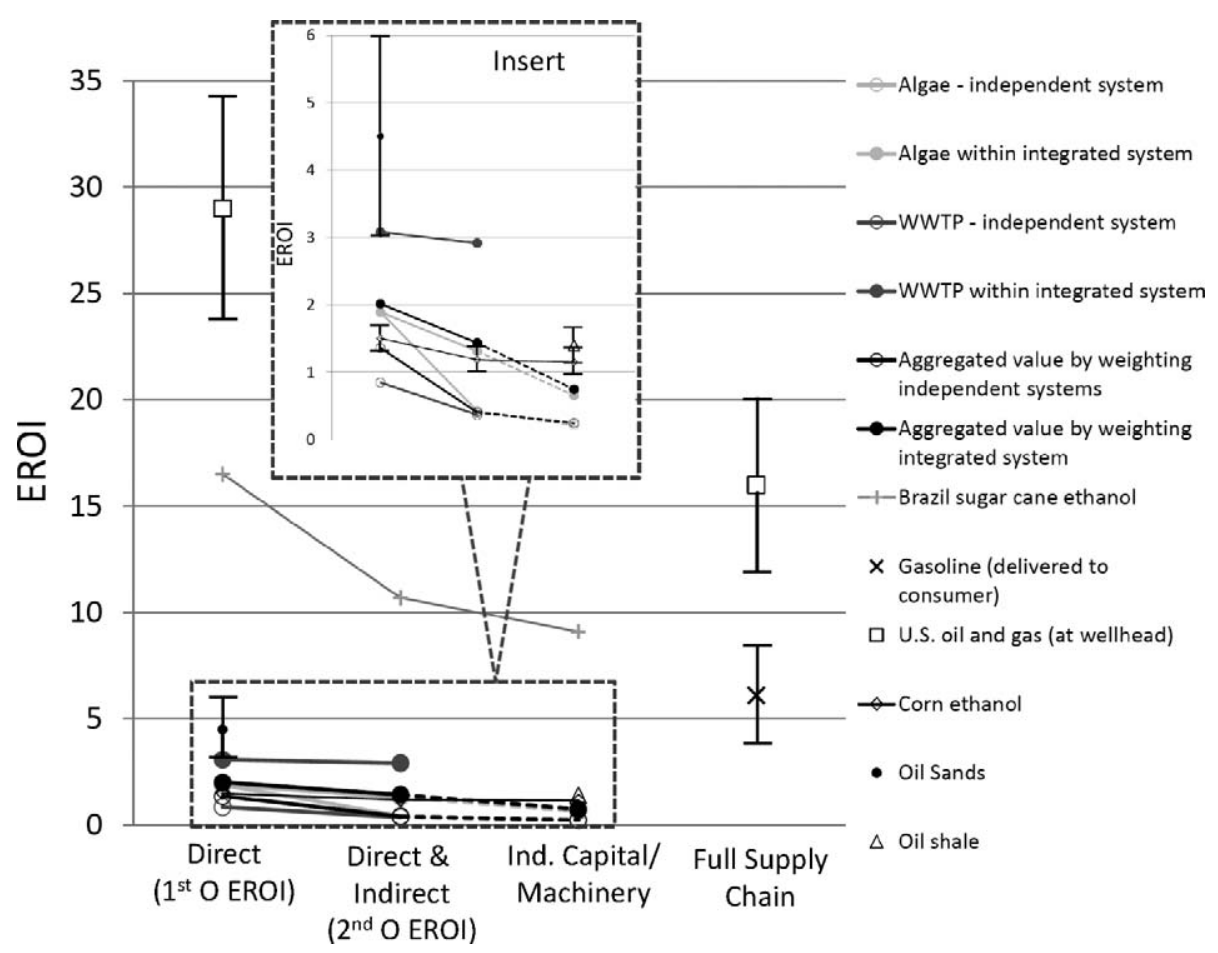

Figure 2-A comparison of the EROI of liquid fuel production from other literature shows that the EROI of algal fuels produced in combination with wastewater treatment are comparable to corn-based ethanol, but that existing sugar cane-based ethanol in Brazil and petroleum gasoline yield much higher EROI. The error bars on the values for both oil and gas (single estimate) and gasoline represent typical ranges ( $+/$ - one standard deviation) over the last 50 years. For the approximation of the EROI for an algal biofuels system operated in combination with wastewater treatment, when considering the energy embodied in capital, the authors assumed capital energy input is $50 \%$ of the total energy input of physical inputs (e.g., inputs besides labor and business costs) based on the results of studies by Davis et al. (2011) and Lundquist et al. (2010).

2009). The processing techniques modeled in this study are the same as those reported previously by Beal et al. (2011a); however, each process has been marginally improved in this model as a result of updated information from ongoing research and development. The integrated system is similar to cases 3 and 5 reported by Lundquist et al. (2010), which include wastewater treatment with bio-oil and methane algal biofuel production.

When operated independently, the quantity of algal biofuels produced is not dependent on the amount of wastewater available because nutrients and $\mathrm{CO}_{2}$ are assumed to be supplied externally. However, when wastewater treatment and algal biofuel systems are combined, the amount of algae that can be produced is dictated by nutrient availability in wastewater. In this analysis, the grown (algal) biomass productivity was specified in the cultivation model. Therefore, in the combined case, the cultivation time is dictated by the amount of time that is required for the limiting nutrient in wastewater (in this case, nitrogen) to be consumed at the specified grown mass production rate. To provide directly comparable results between independent and combined operations, the cultivation time in the independent operations case was assumed to be the same as that in the combined case.

\section{Wastewater Characterization and the Advanced Wastewater}

Treatment Facility. The energy requirements for most of the wastewater treatment processes shown in Figure 1 are derived from Goldstein and Smith (2002). The wastewater influent assumed for this analysis is based on typical composition of wastewater provided by Tchobanoglous et al. (2003). Specifically, the following characteristics are assumed: $140 \mathrm{mg}$ of total organic carbon (TOC)/ $\mathrm{L}_{\mathrm{Ww}}, 75 \mathrm{mg} \mathrm{HCO}_{3} / \mathrm{L}_{\mathrm{Ww}}, 5 \mathrm{mg} \mathrm{CO}_{3} /$ $\mathrm{L}_{\mathrm{WW}}, 40 \mathrm{mg}$ total $\mathrm{N} / \mathrm{L}_{\mathrm{WW}}, 7 \mathrm{mg}$ total $\mathrm{P} / \mathrm{L}_{\mathrm{WW}}$, and $430 \mathrm{mg}$ chemical oxygen demand (COD)/Lww. After primary clarification, in which $0.2 \%$ of the wastewater volume and $40 \%$ of COD is removed as sludge (which has $6 \%$ solids and a specific gravity of 1.02 [Tchobanoglous et al., 2003]), the primary effluent is either delivered for secondary treatment with BNR (independent operations) or delivered to algal cultivation ponds (combined operation). Sturm and Lamer (2011) report that roughly $66 \%$ of the nitrogen and $75 \%$ of the phosphorus in influent wastewater was available in secondary effluent used for algal cultivation. Although the present model assumes primary effluent is used for cultivating algae, the authors assumed that the primary effluent also contains $66 \%$ of the nitrogen and $75 \%$ of the phosphorus from the wastewater (i.e., $26 \mathrm{mg}$ total $\mathrm{N} / \mathrm{L}_{\mathrm{PE}}$ and $5.3 \mathrm{mg}$ total $\mathrm{P} /$ $\left.\mathrm{L}_{\mathrm{PE}}\right)$. In this model, primary effluent contains $84 \mathrm{mg} \mathrm{TOC} / \mathrm{L}_{\mathrm{W} W \mathrm{~W}}$, $75 \mathrm{mg} \mathrm{HCO}_{3} / \mathrm{L}_{\mathrm{WWW}}\left(15 \mathrm{~g} \mathrm{C} / \mathrm{L}_{\mathrm{WW}}\right)$, and $5 \mathrm{mg} \mathrm{CO} / \mathrm{L}_{\mathrm{WW}}(1 \mathrm{mg} \mathrm{C} /$ $\mathrm{L}_{\mathrm{WW}}$ ), totaling $100 \mathrm{mg} \mathrm{C} / \mathrm{L}_{\mathrm{WWW}}$. The carbon, nitrogen, and phosphorus loadings of the primary effluent dictate algal biomass productivity and the effect of nutrient loadings on the EROI are considered in the sensitivity analysis. 
The sludge is processed via anaerobic digestion, which is assumed to produce biogas and yields $0.4 \mathrm{~m}^{3}$ methane/kg COD (Tchobanoglous et al., 2003). The biogas is $65 \%$ methane and $35 \%$ carbon dioxide and contains trace amounts of contaminants such as hydrogen sulfide. Typically, $40 \%$ of the sludge is produced during primary clarification, while $60 \%$ is produced during secondary treatment. Thus, when primary effluent is used for cultivating algae, the sludge volume and associated biogas (and electricity) production are reduced proportionally. Based on this estimate, the heat required to operate anaerobic digestion and the energy required for solids handling are also reduced by $60 \%$ in the combined operations case. The biogas (methane and carbon dioxide) is delivered to a cogeneration facility (with 30\% electricity generation efficiency [Christenson and Sims, 2011; Lundquist et al., 2010]). During independent operations, the biogas combustion produces $4.3 \mathrm{~kJ}$ of heat $/ \mathrm{L}_{\mathrm{Ww}}$ and $1.8 \mathrm{~kJ}$ of electricity/Lww (Tchobanoglous et al., 2003). However, because of lower sludge volumes for digestion in the combined wastewater treatment and algal biofuels system, biogas combustion produces only $1.7 \mathrm{~kJ}$ of heat/ $\mathrm{L}_{\mathrm{W} w \mathrm{~W}}$ and 0.7 $\mathrm{kJ}$ of electricity/ $\mathrm{L}_{\mathrm{w} w \mathrm{w}}$. Assuming complete biogas combustion in both cases, carbon dioxide would be produced containing 145 $\mathrm{mg}$ and $58 \mathrm{mg}$ of carbon per $\mathrm{L}_{\mathrm{Ww}}$ in independent and combined operations, respectively. In the combined system, this carbon dioxide is used for algal cultivation, as described below.

During independent operations, primary effluent is treated by aeration, nitrification, BNR, secondary clarification, filtration, and chlorination and dechlorination, as shown in Figure 1. With the exception of BNR, the energy costs for each step are estimated based on data presented by Goldstein and Smith (2002). The energy required to perform BNR is taken from Sturm and Lamer (2011). The indirect energy inputs (i.e., energy embedded in materials) represent a significant contribution to the second-order energy consumption for wastewater treatment. Based on data from Fleischer et al. (2005), it was assumed that 65 $\mathrm{mg}$ of methanol and $85 \mathrm{mg}$ of alum are required per liter of primary effluent. The energy embedded in these materials is estimated to be $41 \mathrm{MJ} / \mathrm{kg}$ (Capello et al., 2007; Worrell et al., 2000) and $3 \mathrm{MJ} / \mathrm{kg}$ (Arpke and Hutzler, 2006), respectively. For chlorination and dechlorination, it is assumed that $8 \mathrm{mg}$ of chlorine and $2 \mathrm{mg}$ of sulfur dioxide are consumed per liter of primary effluent (Ryder and de Boer, 2009; Tchobanoglous et al., 2003), with embedded energy values of $19 \mathrm{MJ} / \mathrm{kg}$ (Worrell et al., 2000) and $5 \mathrm{MJ} / \mathrm{kg}$ (authors' estimate based on studies by Börjesson [1996], Kim and Overcash [2003], and Worrell et al. [2000], respectively).

Algal Cultivation. Baseline assumptions for growth (in independent and combined operation) include open ponds that are $20-\mathrm{cm}$ deep, a grown mass productivity of $0.08 \mathrm{~g} / \mathrm{L} \cdot \mathrm{d}$ (which is $16 \mathrm{~g} / \mathrm{m}^{2} \cdot \mathrm{d}$ ), which corresponds to a photosynthetic efficiency of about 3.7\% (Beal, 2011; Beal et al., 2012), a neutral lipid fraction (NLF) of 0.1 , and a resulting algal biomass stoichiometry of $\mathrm{C}_{106} \mathrm{H}_{181} \mathrm{O}_{45} \mathrm{~N}_{15} \mathrm{P}$ with a molecular weight of $2414 \mathrm{~g} / \mathrm{mol}$, as provided by Clarens et al. (2010). The open-pond growth setting was selected as a low capital cost option, although capital costs are not explicitly calculated in this study. The grown mass productivity assumptions are based on the experimental data for cultivating algae in wastewater, which have been presented previously (Park and Craggs, 2011; Park et al., 2010; Sturm and Lamer, 2011; Wang and Lan, 2011). For this analysis, ideal uptake rates of nitrogen, phosphorus, and carbon are assumed, and nitrogen was determined to be the limiting resource in wastewater based on stoichiometric requirements. For each gram of algal biomass produced, $0.53 \mathrm{~g}$ of carbon (or $1.77 \mathrm{~g}$ of $\mathrm{CO}_{2}$ ), $0.09 \mathrm{~g}$ of nitrogen, and $0.01 \mathrm{~g}$ of phosphorus are required. The primary effluent contains $26 \mathrm{mg} \mathrm{N} / \mathrm{L}_{\mathrm{PE}}$, which, with a $100 \%$ uptake rate, would yield $303 \mathrm{mg}$ algae/ $\mathrm{L}_{\mathrm{PE}}$. Producing $303 \mathrm{mg}$ algae $/ \mathrm{L}_{\mathrm{PE}}$ at $0.08 \mathrm{~g} / \mathrm{L} \cdot \mathrm{d}$ yields a cultivation time of 3.8 days. As mentioned previously, although cultivating algae independently from wastewater treatment would not be constrained by nutrient availability and the cultivation time could, therefore, be extended to allow higher algal concentrations, for the sake of direct comparison it is assumed that the cultivation time is 3.8 days in the independent operations case as well. This identical cultivation time allows for direct comparison of EROI values from independent wastewater treatment and algal biofuels facilities and the combined operations facility.

Based on data presented by Yang et al. (2010), it is estimated that evaporation would consume about $4 \mathrm{~L} / \mathrm{m}^{2} \cdot \mathrm{d}$ of culture water (equivalent to $24 \mathrm{~mL} / \mathrm{L} \cdot \mathrm{d}$ ). Based on this value and the grown mass productivity stated previously, $0.09 \mathrm{~L}$ of water would evaporate during the cultivation time (3.8 days) per liter of processed water, yielding a primary effluent-to-processed water ratio of 1.09 (and a wastewater-to-processed water ratio of 1.09). As a result, the algal density at the time of harvest would be $331 \mathrm{mg} / \mathrm{L}_{\mathrm{PW}}$, which is consistent with typical yields from open-pond systems.

In independent operation, the energy required for growth includes direct energy required for water supply, nutrient supply (including $\mathrm{CO}_{2}$ ), and mixing, and indirect energy associated with water, carbon, nitrogen, phosphorus, and antibiotic inputs (Beal, 2011; Beal et al, 2011a). Table 2 lists data used to calculate the energy consumed for cultivation during independent operations, which are based on the Highly Productive Case presented by Beal et al. (2011a). The Highly Productive Case is an analytical model designed to represent efficient operation of growth and processing technologies that were developed at the University of Texas at Austin and have been tested on large-scale batches of several thousand liters of growth volume (i.e., the Experimental Case) (Beal et al., 2011a). In the Highly Productive Case scenario, it is assumed that $95 \%$ of processed water is recycled, and energy consumed for supplying water to the growth volume is $1.3 \mathrm{~kJ} / \mathrm{L}$ (King et al., 2008). The embedded energy in $\mathrm{CO}_{2}$, nitrogen, phosphorus, and antibiotics was estimated to be $7 \mathrm{MJ} / \mathrm{kg}$ (Clarens et al., 2010; Murphy, 2010), $59 \mathrm{MJ} / \mathrm{kg}$ (Clarens et al., 2010; Murphy, 2010; NREL, 2008; Ramírez and Worrell, 2006; Sheehan et al., 2000; Worrell et al., 2000; Wu et al., 2007), 44 MJ/ kg (Clarens et al., 2010; Murphy, 2010; Ramírez and Worrell, 2006), and $50 \mathrm{MJ} / \mathrm{kg}$ (authors' estimate based on work by Börjesson [1996]), respectively. Mixing is modeled as consuming $100 \mathrm{~J} / \mathrm{L} \cdot \mathrm{d}$ (Table 5 of Beal et al. [2011a]), which is equivalent to $0.38 \mathrm{~kJ} / \mathrm{L}_{\mathrm{PW}}$ (based on 3.8 days of cultivation time).

In the combined wastewater treatment and algal biofuels system, the water, nitrogen, and phosphorus are assumed to be available via gravity flow of primary effluent. Thus, it is assumed that these inputs do not contain any embedded energy (Table 4). The carbon dioxide exhaust from the co-generator (at 5\% $\mathrm{CO}_{2}$ in air [Klara, 2007]) is collected and pumped to the algae ponds. The head loss associated with pumping the exhaust gas includes losses incurred for pipe flow (200 Pa, assuming a pumping distance of $200 \mathrm{~m}$ on average) and hydrostatic pressure (1960 Pa for $0.2 \mathrm{~m}$ of water). Assuming a pump efficiency of $70 \%$ results 
Table 1-Independent WWTP energy data. Data are reported per liter of wastewater and it is assumed that the wastewater-toprocessed water ratio is 1.09 .

\begin{tabular}{|c|c|c|c|}
\hline & Amount consumed ( $X$ per $\left.L_{w w}\right)$ & Energy equivalent $(\mathrm{J} / \mathrm{X})$ & Energy $\left(\mathrm{J} / \mathrm{L}_{\mathrm{ww}}\right)$ \\
\hline Pumping $\left(\mathrm{J} / \mathrm{L}_{\mathrm{ww}}\right)$ & 133.35 & 1 & 133 \\
\hline Bar screens $\left(\mathrm{J} / \mathrm{L}_{\mathrm{ww}}\right)$ & 0.19 & 1 & 0.19 \\
\hline Grit chamber $\left(\mathrm{J} / \mathrm{L}_{\mathrm{ww}}\right)$ & 12.75 & 1 & 12.8 \\
\hline Pretreatment total (bar screens and grit chamber) $\left(\mathrm{J} / \mathrm{L}_{\mathrm{ww}}\right)$ & & & 12.9 \\
\hline Primary Settling $\left(\mathrm{J} / \mathrm{L}_{w w}\right)_{\tilde{z}}$ & 14.74 & 1 & 14.7 \\
\hline Primary treatment total $\tilde{E}_{P T}$ & & & 161 \\
\hline Aeration $\left(\mathrm{J} / \mathrm{L}_{\mathrm{ww}}\right)$ & 506.00 & 1 & 506 \\
\hline Nitrification $\left(\mathrm{J} / \mathrm{L}_{\mathrm{ww}}\right)$ & 327.76 & 1 & 328 \\
\hline BNR energy $\left(\mathrm{J} / \mathrm{L}_{\mathrm{ww}}\right)$ & 723.80 & 1 & 724 \\
\hline BNR methanol (mg/Lww) & 65.16 & 40.7 & 2650 \\
\hline BNR alum $\left(\mathrm{mg} / \mathrm{L}_{w w}\right)$ & 85.21 & 2.88 & 245 \\
\hline BNR total (energy, methanol, and alum) $\left(\mathrm{J} / \mathrm{L}_{w w}\right)$ & & & 3620 \\
\hline Secondary settling $\left(\mathrm{J} / \mathrm{L}_{\mathrm{ww}}\right)$ & 14.74 & 1 & 14.7 \\
\hline Mixing energy $\left(\mathrm{J} / \mathrm{L}_{\mathrm{ww}}\right)$ & 52.50 & 1 & 52.5 \\
\hline Mixing chemicals (mg/Lww) & 0 & NA & 0 \\
\hline Filter $\left(\mathrm{J} / \mathrm{L}_{\mathrm{ww}}\right)$ & 114.80 & 1 & 115 \\
\hline Chlorination energy $\left(\mathrm{J} / \mathrm{L}_{w w}\right)$ & 2.57 & 1 & 2.57 \\
\hline Chlorine (mg/Lww) & 7.98 & 19.2 & 153 \\
\hline Dechlorination material (sulfur dioxide) (mg/Lww) & 2.00 & 5 & 9.98 \\
\hline Chlorination and dechlorination total $\left(\mathrm{J} / \mathrm{L}_{w w}\right)$ & & & 166 \\
\hline Secondary treatment total $\tilde{E}_{S T}$ & & & 4800 \\
\hline Pumping of primary solids $\left(\mathrm{J} / \mathrm{L}_{w w}\right)$ & 32.21 & 1 & 32.2 \\
\hline Flotation thickening of secondary solids $\left(\mathrm{J} / \mathrm{L}_{w w}\right)$ & 192.32 & 1 & 192.3 \\
\hline Gravity thickening of secondary solids $\left(\mathrm{J} / \mathrm{L}_{\mathrm{ww}}\right)$ & 2.38 & 1 & 2.38 \\
\hline Pump secondary solids to digester ( $\left.\mathrm{J} / \mathrm{L}_{w w}\right)$ & 48.32 & 1 & 48.3 \\
\hline Anaerobic digester heat $\left(\mathrm{J} / \mathrm{L}_{w w}\right)$ & 161.69 & 1 & 162 \\
\hline Solids handling $\left(\mathrm{J} / \mathrm{L}_{\mathrm{ww}}\right)$ & 43.47 & 1 & 43.5 \\
\hline Sludge processing total (primary and secondary) $\tilde{E}_{S P}$ & & & 480 \\
\hline Total energy input $\tilde{E}_{W w T}$ & & & 5440 \\
\hline Electricity $\left(\mathrm{J} / \mathrm{L}_{\mathrm{ww}}\right) E D_{E}$ & 1844.70 & 1 & 1840 \\
\hline Heat for digester $\left(\mathrm{J} / \mathrm{L}_{\mathrm{ww}}\right) E D_{D H}$ & 161.69 & 1 & 162 \\
\hline Excess heat $\left(\mathrm{J} / \mathrm{L}_{\mathrm{ww}}\right)$ & 4142.61 & 0 & 0 \\
\hline Landfill solids (J/Lww) & NA & 0 & 0 \\
\hline Total energy output & & & 2000 \\
\hline $2^{n d} O E^{n R O} I_{W W T}$ & & & 0.37 \\
\hline
\end{tabular}

in energy consumption of $54 \mathrm{~J} / \mathrm{g}$ of $\mathrm{CO}_{2}$, where, for $234 \mathrm{mg} \mathrm{CO} /$ $\mathrm{L}_{\mathrm{WW}}$, the energy requirement for pumping is equivalent to $13 \mathrm{~J} /$ LPW.

The algal biomass production is nitrogen-limited (consuming $100 \%$ of the $26 \mathrm{mg}$ of $\mathrm{N} / \mathrm{L}_{\mathrm{PE}}$ ) and requires $161 \mathrm{mg}$ of $\mathrm{C} / \mathrm{L}_{\mathrm{PE}}$ and 4 mg of $\mathrm{P} / \mathrm{L}_{\mathrm{PE}}$, which represents $103 \%$ and $57 \%$ of the carbon and phosphorus content in the raw wastewater, respectively. The small disparity between the stoichiometric carbon requirement (161 $\mathrm{mg} / \mathrm{L}_{\mathrm{PE}}$ ) and the carbon provided to the growth volume $\left(100 \mathrm{mg} / \mathrm{L}_{\mathrm{PE}}\right.$ from primary effluent and $58 \mathrm{mg} / \mathrm{L}_{\mathrm{PE}}$ from flue gas, totaling $158 \mathrm{mg} / \mathrm{L}_{\mathrm{PE}}$ ) is neglected, as it is assumed that the additional carbon could be supplied from air or the algal stoichiometry might change slightly.

The culture would be carbon-limited if there were significant losses in the transfer of carbon dioxide from the pipeline to the pond water, the carbon uptake rate was less than $100 \%$ (i.e., less than $100 \%$ of the carbon added to the culture was assimilated into algal biomass), or the nitrogen content in the primary effluent was higher. Overall, the energy balance would be negatively affected if the culture were carbon-limited. For instance, there would not be enough algal growth to consume all of the nitrogen and phosphorus, necessitating additional energy-intensive nutrient removal processes to satisfy wastewater discharge criteria. Alternatively, the culture could be supplied with additional carbon to prevent carbon limitation, which represents an additional energy input, thereby negatively affecting the overall energy balance. Real cultures are inevitably prone to carbon-limited growth because of imperfections in the design of carbon dioxide delivery systems and fluctuations in temperature and $\mathrm{pH}$, which affect the solubility and speciation of carbon dioxide in the culture media. These fluctuations are highly sensitive to system design, local climate, and operational parameters. Thus, for this analysis, it was assumed that $100 \%$ of the carbon flux supplied to the pond is available for algal growth. Furthermore, the effect of nutrient loadings in wastewater was considered in the sensitivity analysis.

Algae Processing. The processing methods modeled in this study are based on the technologies developed at the University of Texas at Austin and include harvesting via chemical flocculation (Choi, 2009), electromechanical cell lysing (Beal, 2011; Connelly et al., In Preparation), and neutral lipid (i.e., biocrude) separation using a membrane contactor (Beal, 2011). At the time of harvest, the growth volume was identical in the independent case and the combined case, and, therefore, the 
Table 2-Independent algal biofuel production pathway energy data. Data are reported per liter of processed water and it is assumed that the wastewater-to-processed water ratio is $\mathbf{1 . 0 9}$.

\begin{tabular}{|c|c|c|c|}
\hline & Amount consumed ( $X$ per $\left.L_{P W}\right)$ & Energy equivalent $(\mathrm{J} / \mathrm{X})$ & Energy $\left(\mathrm{J} / \mathrm{L}_{\mathrm{PW}}\right)$ \\
\hline Direct water (L/LPW) & 0.05 & $0^{1}$ & 0.00 \\
\hline Water supply energy (J/L & 1.09 & $1330^{1}$ & 1450 \\
\hline $\mathrm{CO}_{2}(\mathrm{mg} / \mathrm{L})$ & 585.93 & $7.33^{2}$ & 4290 \\
\hline $\mathrm{CO}_{2}$ supply energy $\left(\mathrm{J} / \mathrm{L}_{\mathrm{PW}}\right)$ & 585.93 & $0^{2}$ & 0.00 \\
\hline Nitrogen ( $\left.g / L_{p w}\right)$ & 26.40 & 59 & 1560 \\
\hline Phosphorus (mg/Lpw) & 4.39 & 44 & 193 \\
\hline Antibiotics (mg/L & 0.09 & 50 & 4.73 \\
\hline Mixing (kJ/Lpw) & 379.34 & 1 & 379 \\
\hline Growth total $\tilde{E}_{G}$ & & & 7880 \\
\hline Pump from pond (J/L & 955.00 & 1 & 955 \\
\hline Flocculants (g/L $\left.L_{p w}\right)$ & 33.11 & 5 & 166 \\
\hline Deflocculants ( $\left.g / L_{p w}\right)$ & 82.78 & 7.33 & 607 \\
\hline Additional harvesting energy ( $\left.\mathrm{J} / \mathrm{L}_{\mathrm{PW}}\right)$ & 500.00 & 1 & 500 \\
\hline Harvesting total & & & 2230 \\
\hline Water recycling/treatment energy $\left(\mathrm{J} / \mathrm{L}_{\mathrm{PW}}\right)$ & 2.53050 & 1 & 2.53 \\
\hline Water treatment chlorine $\left(\mathrm{mg} / \mathrm{L}_{\mathrm{PW}}\right)$ & 7.88 & 19.23 & 152 \\
\hline Water treatment dechlorination (Sulfur dioxide) (mg/LPW) & 1.97 & 5.00 & 9.85 \\
\hline Water recycling total & & & 164 \\
\hline Pump (J/L $\left.L_{p w}\right)$ & 0.00 & 1 & 0.00 \\
\hline Power supply $\left(\mathrm{J} / \mathrm{L}_{\mathrm{PW}}\right)$ & 30.38 & 1 & 30.4 \\
\hline Lysing total & & & 30.4 \\
\hline Separations energy (J/LPw) & 0.0090 & 1 & 0.01 \\
\hline Distillation energy (J/Lpw) & 188.20 & 1 & 188 \\
\hline Chill water (mL/LPW) & 4.23 & 11.23 & 47.5 \\
\hline Heptane loss (mL/LPW) & 0.00 & 41.75 & 0.00 \\
\hline Separations total & & & 236 \\
\hline Processing total $\tilde{E}_{P}$ & & & 2660 \\
\hline Bio-oil refining energy (J/L $\left.L_{P W}\right)$ & 53.49 & 1 & 53.5 \\
\hline Bio-oil refining materials (mg/Lpw) & 2.42 & 40.7 & 98.5 \\
\hline Biomass fuel refining (J/Lpw) & 372.75 & 1 & 373 \\
\hline Refining total $\tilde{E}_{R}$ & & & 525 \\
\hline Total energy input & & & 11000 \\
\hline Bio-oil (mg/LPW) É $D_{B O}$ & 24.20 & 40 & 968 \\
\hline Methane $\left(\mathrm{mg} / \mathrm{L}_{\mathrm{PW}}\right) E D_{M}$ & 67.77 & 55 & 3730 \\
\hline Total energy output & & & 4700 \\
\hline $2^{\text {nd }} O \mathrm{EROI}_{B F}$ & & & 0.42 \\
\hline
\end{tabular}

${ }^{1}$ No energy is required for "manufacturing" water and the energy required to treat and pump water to the algae facility is included in the energy equivalent for water supply.

${ }^{2}$ Carbon dioxide is added from compressed tanks, with the energy for compression included in the energy equivalent, thereby not requiring additional energy for supply.

harvesting, lysing, separations, and refining steps were also identical.

Harvesting. The harvesting process is modeled as a $\mathrm{pH}$-sweep chemical flocculation method in which algae are flocculated by raising the $\mathrm{pH}$ using alkalizing agents and subsequently deflocculated (Choi, 2009; Knuckey et al., 2006; Molina Grima et al., 2003; Tchobanoglous et al., 2003; Yahi et al., 1994). The process is modeled as achieving a $65 \times$ concentration factor with a harvesting efficiency $\left(\varphi_{\text {harv }}\right)$ of $95 \%$. Thus, the algal concentrate volume will be $1.5 \%$ of the processed water volume, with an algal concentration of $21.5 \mathrm{~g} / \mathrm{L}_{\mathrm{AC}}$. The discharge water volume will be $98.5 \%$ of the processed water volume with an algal concentration of $32 \mathrm{mg} / \mathrm{L}_{\mathrm{DW}}$, a negligible nitrogen content, and an acceptable phosphorus content for discharge (as the excess phosphorus in the growth volume is precipitated via chemical flocculation and collected with the algal concentrate). As with all processing steps, there are several alternative harvesting methods that have been described previously (Amin, 2009; Molina Grima et al., 2003; Wiley et al., 2011), such as centrifugation, dissolved air flotation, and auto-flocculation, and each process requires different direct and indirect energy expenses.

As shown in Tables 2 and 4, energy requirements for the harvesting process include the direct energy consumed for pumping the algae $10 \mathrm{~m}$ to the harvesting facility (modeled as $0.96 \mathrm{~kJ} / \mathrm{L}_{\mathrm{PW}}$ [Beal et al., 2011a]); indirect energy embedded in flocculants $(100 \mathrm{mg} / \mathrm{g}$ algae with an energy equivalent of $5 \mathrm{MJ} / \mathrm{kg}$ of flocculation chemical [Arpke and Hutzler, 2006; Börjesson, 1996]); indirect energy embedded in deflocculants $(250 \mathrm{mg} / \mathrm{g}$ algae with an energy equivalent of $7 \mathrm{MJ} / \mathrm{kg}$ [Beal et al., 2011a; Clarens et al., 2010; Murphy, 2010]) consumed during the flocculation and deflocculation process; and additional energy required to operate the harvesting unit (e.g., pumping, mixing, metering, etc., which is estimated as approximately $0.5 \mathrm{~kJ} / \mathrm{L}_{\mathrm{PW}}$ ). The discharge water will likely require a chlorination and 
Table 3-Energy consumption and production for a WWTP operated in conjunction with algal biofuel production. Data are reported per liter of wastewater and the wastewater-to-processed water ratio is $\mathbf{1 . 0 9}$.

\begin{tabular}{|c|c|c|c|}
\hline & Amount consumed ( $X$ per $L_{w w}$ ) & Energy equivalent $(\mathrm{J} / \mathrm{X})$ & Energy $\left(\mathrm{J} / \mathrm{L}_{\mathrm{ww}}\right)$ \\
\hline Pumping $\left(\mathrm{J} / \mathrm{L}_{w w}\right)$ & 133.35 & 1 & 133 \\
\hline Bar screens $\left(\mathrm{J} / \mathrm{L}_{\mathrm{ww}}\right)$ & 0.19 & 1 & 0.19 \\
\hline Grit chamber $\left(\mathrm{J} / \mathrm{L}_{w w}\right)$ & 12.75 & 1 & 12.8 \\
\hline Pretreatment total (bar screens and grit chamber) $\left(\mathrm{J} / \mathrm{L}_{w w}\right)$ & & & 12.9 \\
\hline Primary settling $\left(\mathrm{J} / \mathrm{L}_{\mathrm{ww}}\right)$ & 14.74 & 1 & 14.7 \\
\hline Primary treatment total $\tilde{E}_{P T}$ & & & 161 \\
\hline Aeration $\left(\mathrm{J} / \mathrm{L}_{\mathrm{ww}}\right)$ & 0 & 1 & 0 \\
\hline Nitrification (J/Lww) & 0 & 1 & 0 \\
\hline BNR energy $\left(\mathrm{J} / \mathrm{L}_{w w}\right)$ & 0 & 1 & 0 \\
\hline BNR methanol (mg/Lww) & 0 & 40.7 & 0 \\
\hline BNR alum $\left(\mathrm{mg} / \mathrm{L}_{\mathrm{ww}}\right)$ & 0 & 2.88 & 0 \\
\hline BNR total (energy, methanol, and alum) $\left(\mathrm{J} / \mathrm{L}_{w w}\right)$ & & & 0 \\
\hline Secondary settling $\left(\mathrm{J} / \mathrm{L}_{w w}\right)$ & 0 & 1 & 0 \\
\hline Mixing energy $\left(\mathrm{J} / \mathrm{L}_{\mathrm{ww}}\right)$ & 0 & 1 & 0 \\
\hline Mixing chemicals (mg/Lww) & 0 & NA & 0 \\
\hline Filter $\left(\mathrm{J} / \mathrm{L}_{w w}\right)$ & 0 & 1 & 0 \\
\hline Chlorination energy $\left(\mathrm{J} / \mathrm{L}_{\mathrm{ww}}\right)$ & 0 & 1 & 0 \\
\hline Chlorine (mg/Lww) & 0 & 19.23 & 0 \\
\hline Dechlorination material (sulfur dioxide) (mg/Lww) & 0 & 5 & 0 \\
\hline Chlorination and dechlorination total $\left(\mathrm{J} / \mathrm{L}_{w w}\right)$ & & & 0 \\
\hline Secondary treatment total $\tilde{E}_{S T}$ & & & 0 \\
\hline Pumping of primary solids (J/Lww) & 32.21 & 1 & 32.2 \\
\hline Flotation thickening of secondary solids (J/Lww) & 0 & 1 & 0 \\
\hline Gravity thickening of secondary solids $\left(\mathrm{J} / \mathrm{L}_{\mathrm{ww}}\right)$ & 0 & 1 & 0 \\
\hline Pump secondary solids to digester ( $\left.\mathrm{J} / \mathrm{L}_{w w}\right)$ & 0 & 1 & 0 \\
\hline Anaerobic digester heat $\left(\mathrm{J} / \mathrm{L}_{w w}\right)$ & 64.68 & 1 & 64.7 \\
\hline Solids handling $\left(\mathrm{J} / \mathrm{L}_{w w}\right)$ & 17.39 & 1 & 17.4 \\
\hline Sludge processing total (primary and secondary) $\tilde{E}_{S P}$ & & & 114 \\
\hline Total energy input $\tilde{E}_{W W T}$ & & & 275 \\
\hline Electricity $\left(\mathrm{J} / \mathrm{L}_{\mathrm{ww}}\right) E D_{E}$ & 737.88 & 1 & 738 \\
\hline Heat for digester $\left(\mathrm{J} / \mathrm{L}_{\mathrm{ww}}\right) E D_{D H}$ & 64.68 & 1 & 64.7 \\
\hline Excess heat $\left(\mathrm{J} / \mathrm{L}_{\mathrm{ww}}\right)$ & 1560.03 & 0 & 0 \\
\hline Landfill solids $\left(\mathrm{J} / \mathrm{L}_{\mathrm{ww}}\right)$ & NA & 0 & 0 \\
\hline Total energy output & & & 803 \\
\hline $2^{\text {nd }} O E R O I_{W W T}$ & & & 2.92 \\
\hline
\end{tabular}

dechlorination process, as illustrated in Figure 1, because of the presence of unrecovered algae and bacteria.

Lysing. The lysing process consists of applying an electric field to compromise the cell membrane. The energy consumption modeled for this process is based on a unipolar power supply system designed and constructed at The University of Texas at Austin, which consumes $2 \mathrm{~kJ} / \mathrm{L}_{\mathrm{AC}}\left(0.03 \mathrm{~kJ} / \mathrm{L}_{\mathrm{PW}}\right)$ for a concentrate conductivity of $1 \mathrm{mS} / \mathrm{cm}$. The cell lysing efficiency, $\varphi_{\text {cellys }}$, is 95\% (Beal, 2011; Beal et al., 2011a).

Separations. The separations process is based on analysis presented for the Highly Productive Case of (Beal et al., 2011a), which results in a total energy requirement for separations of $0.24 \mathrm{~kJ} / \mathrm{L}_{\mathrm{PW}}$. This value includes direct energy required to operate the membrane contactor, direct energy consumed for distillation, and indirect energy embedded in the solvent (heptane with an energy equivalent of $42 \mathrm{MJ} / \mathrm{kg}$ (Capello et al., 2007) and chilled water (with an energy equivalent of $11 \mathrm{~kJ} / \mathrm{L}$ [Beal et al., 2011a]) consumed during the process. Using a solventless extraction process reduces the separations energy requirement. The biocrude separations efficiency, $\varphi_{\text {sep } \mathrm{BC}}$, is the amount of neutral lipids recovered via separations divided by the mass of lysed algal biomass and is assumed to be 0.09 (Beal et al., 2011a; Beal et al., 2011b). The NLF is embedded in the biocrude separations efficiency. The biomass slurry separations efficiency, $\varphi_{\text {sep BS }}$, is the amount of biomass recovered in the postextraction slurry divided by the mass of lysed algal biomass, and is assumed to be 0.9 (Beal et al., 2011a; Beal et al., 2011b).

Biofuel Refining. This study assumes as part of its model that the biocrude is upgraded to bio-oil (e.g., renewable diesel) and that the required energy and materials are based on data presented by Batan et al. (2010) and Lardon et al. (2009). The bio-oil refining efficiency, $\varphi_{\text {ref }}$ во, is $90 \%$, and the process requires $0.05 \mathrm{~kJ} / \mathrm{L}_{\mathrm{PW}}$ of direct energy input. In addition, the biooil refining process requires $0.09 \mathrm{~kJ} / \mathrm{L}_{\mathrm{PW}}$ of indirect energy associated with energy embedded in refining materials (i.e., methanol, with an energy equivalent of $41 \mathrm{MJ} / \mathrm{kg}$ [Capello et al., 2007; Worrell et al., 2000]).

The biomass slurry is modeled as being converted to methane via catalytic hydrothermal gasification, which is a process developed by Genifuel (Oyler, 2010) and described previously (Beal et al., 2011a). Catalytic hydrothermal gasification can produce $0.25 \mathrm{~g}$ of methane per gram of algae in the biomass slurry (thus, the methane refining efficiency, $\varphi_{\text {ref } \mathrm{M}}$, is 0.25 ) and 
Table 4-Energy consumption and production data for an algal biofuels system operated in conjunction with wastewater treatment. Data are reported per liter of processed water and the wastewater-to-processed water ratio is 1.09 .

\begin{tabular}{|c|c|c|c|}
\hline & Amount consumed (X per $\left.\mathrm{L}_{\mathrm{PW}}\right)$ & Energy equivalent $(\mathrm{J} / \mathrm{X})$ & Energy $\left(\mathrm{J} / \mathrm{L}_{\mathrm{PW}}\right)$ \\
\hline Direct water $\left(\mathrm{L} / \mathrm{L}_{\mathrm{PW}}\right)$ & 1.09 & $0^{1}$ & 0 \\
\hline Water supply energy (J/LPW) & 1.09 & $0^{1}$ & 0 \\
\hline $\mathrm{CO}_{2}(\mathrm{mg} / \mathrm{L})$ & 234.37 & $0^{2}$ & 0 \\
\hline $\mathrm{CO}_{2}$ supply energy $\left(\mathrm{J} / \mathrm{L}_{\mathrm{PW}}\right)$ & 234.37 & $0.05^{2}$ & 12.6 \\
\hline Nitrogen ( $\left.g / L_{P W}\right)$ & 26.40 & $0^{1}$ & 0 \\
\hline Phosphorus (mg/ $\mathrm{L}_{\mathrm{PW}}$ ) & 4.02 & $0^{1}$ & 0 \\
\hline Antibiotics (mg/LPW) & 0.09 & 50 & 4.73 \\
\hline Mixing $\left(\mathrm{kJ} / \mathrm{L}_{\mathrm{PW}}\right)_{\tilde{z}}$ & 379.34 & 1 & 379 \\
\hline Growth total $\tilde{E}_{G}$ & & & 397 \\
\hline Pump from pond (J/LPW) & 955.00 & 1 & 955 \\
\hline Flocculants ( $\left.g / L_{P W}\right)$ & 33.11 & 5 & 166 \\
\hline Deflocculants ( $\left.g / L_{P W}\right)$ & 82.78 & 7.33 & 607 \\
\hline Additional harvesting energy $\left(\mathrm{J} / \mathrm{L}_{\mathrm{PW}}\right)$ & 500.00 & 1 & 500 \\
\hline Harvesting total & & & 2230 \\
\hline Water recycling/treatment energy $\left(\mathrm{J} / \mathrm{L}_{\mathrm{PW}}\right)$ & 2.53 & 1 & 2.53 \\
\hline Water treatment chlorine $\left(\mathrm{mg} / \mathrm{L}_{\mathrm{PW}}\right)$ & 7.88 & 19.2 & 152 \\
\hline Water treatment dechlorination (Sulfur dioxide) (mg/Lpw) & 1.97 & 5 & 9.85 \\
\hline Water recycling total & & & 164 \\
\hline Pump (J/L & 0.00 & 1 & 0.00 \\
\hline Power supply (J/LPW) & 30.38 & 1 & 30.4 \\
\hline Lysing total & & & 30.4 \\
\hline Separations energy $\left(\mathrm{J} / \mathrm{L}_{\mathrm{PW}}\right)$ & 0.01 & 1 & 0.01 \\
\hline Distillation energy (J/Lpw) & 188.20 & 1 & 188 \\
\hline Chill water (mL/L & 4.23 & 11.23 & 47.5 \\
\hline Heptane loss (mL/LPW) & 0.00 & 41.75 & 0.00 \\
\hline Separations total & & & 236 \\
\hline Processing total $\tilde{E}_{P}$ & & & 2660 \\
\hline Bio-oil refining energy $\left(\mathrm{J} / \mathrm{L}_{\mathrm{PW}}\right)$ & 53.49 & 1 & 53.5 \\
\hline Bio-oil refining materials $\left(\mathrm{mg} / \mathrm{L}_{\mathrm{PW}}\right)$ & 2.42 & 40.7 & 98.5 \\
\hline Biomass fuel refining $\left(\mathrm{J} / \mathrm{L}_{\mathrm{PW}}\right)$ & 372.75 & 1 & 373 \\
\hline Refining total $\tilde{E}_{R}$ & & & 525 \\
\hline Total energy input & & & 3680 \\
\hline Bio-oil (mg/LPW) $E D_{B O}$ & 24.20 & 40 & 968 \\
\hline Methane $\left(\mathrm{mg} / \mathrm{L}_{\mathrm{PW}}\right) E D_{M}$ & 67.77 & 55 & 3730 \\
\hline Total energy output & & & 4700 \\
\hline $2^{\text {nd }} O \mathrm{EROI}_{B F}$ & & & 1.31 \\
\hline
\end{tabular}

consumes about $10 \%$ of the methane produced for its own operation $\left(0.35 \mathrm{~kJ} / \mathrm{L}_{\mathrm{PW}}\right)$.

Biofuel Yields. The bio-oil and methane productivities of this system can be reported as

$$
P_{B O}=P_{G M} \cdot \varphi_{\text {harv }} \cdot \varphi_{\text {cellys }} \cdot \varphi_{\text {sep }_{B C}} \cdot \varphi_{\text {ref }_{B O}}\left[\frac{g}{L_{P W}-d}\right]
$$

and

$$
P_{M}=P_{G M} \cdot \varphi_{\text {harv }} \cdot \varphi_{\text {cellys }} \cdot \varphi_{\text {sep }} \cdot \varphi_{\text {ref }_{M}}\left[\frac{g}{L_{P W}-d}\right]
$$

Where

$P=$ the productivity of bio-oil $(B O)$, methane $(M)$, and grown mass $(G M)$, and

$\varphi=$ the efficiency of harvesting (harv), cell lysing (cellys), separations (sep) of biocrude $(B C)$ and biomass in the postextraction slurry $(B S)$ and refining (ref).
Each efficiency is defined as the mass of the output divided by the mass of the input for that step (Beal et al., 2011b). The energy yield of the bio-oil and methane, per liter of processed water, is

$$
E^{\prime} D_{B O}=P_{B O} \cdot t_{c} \cdot v_{B O}\left[\frac{k J}{L_{P W}}\right]
$$

and

$$
\dot{E} D_{M}=P_{M} \cdot t_{c} \cdot v_{M}\left[\frac{k J}{L_{P W}}\right]
$$

Where

$t_{c}=$ the cultivation time (3.8 days),

$v_{B O}=$ the bio-oil energy content $(40 \mathrm{MJ} / \mathrm{kg})$, and

$v_{M}=$ the methane energy content $(55 \mathrm{MJ} / \mathrm{kg})$.

Energy Return on Investment Framework and Net Energy Effect Ratio. The $2^{\text {nd }} O E R O I$ is calculated for the wastewater 
treatment facility and the algal biofuel production system independently according to the framework provided by Mulder and Hagens (2009); process-specific terminology and nomenclature is based on the framework provided by Beal et al. (2011b). This metric includes direct and indirect operating energy expenses that are shown in Figure 1, but it neglects capital, labor, and externalities. For the nomenclature used, a tilde indicates energy associated with a production step and an apostrophe accent denotes volumetric data with respect to a liter of wastewater or processed water.

For the WWT facility, the $2^{\text {nd }} \mathrm{O} E R O I$ is

$$
2^{n d} O E R O I_{W W T}=\frac{E^{\prime} D_{E}+E^{\prime} D_{D H}}{\widetilde{E}_{P T}+\widetilde{E}_{S T}+\widetilde{E}_{S P}}\left[\frac{k J / L_{W W}}{k J / L_{W W}}\right]
$$

Where

$\widetilde{E}_{P T}=$ the energy consumed by primary treatment (which includes pumping, the grit chamber, and primary clarification);

$\widetilde{E}_{S T}=$ the energy consumed for secondary treatment (which includes aeration, nitrification, BNR, secondary clarification, mixing and filtration, and chlorination and dechlorination), and

$\widetilde{E}_{S P}=$ sludge processing (which includes secondary sludge thickening, anaerobic digestion, solids handling, and cogeneration).

Energy outputs from wastewater treatment include electricity produced via cogeneration $\left(E D_{E}\right)$ and useful heat returned to the anaerobic digester $\left(E D_{D H}\right)$. Excess heat is assigned an energy equivalent of zero and it is assumed for this analysis that solids produced from anaerobic digestion are disposed of in a landfill. If the digested solids are used for fertilizer or incinerated with associated electricity production, the energy equivalent of those products should be added to the numerator of eq 5 .

The $2^{\text {nd }} O E R O I$ of the algal biofuels production pathway can be calculated as

$$
2^{n d} O E R O I_{B F}=\frac{\dot{E} D_{B O}+\dot{E} D_{M}}{\breve{E} D_{G}+\widetilde{E}_{P}+\widetilde{E}_{R}}\left[\frac{k J / L_{P W}}{k J / L_{P W}}\right]
$$

where $\widetilde{E}_{G}, \widetilde{E}_{P}$, and $\widetilde{E}_{R}$ are the energy requirements for growth, processing (which includes harvesting, water recycling and treatment, cell lysing, and lipid separation), and refining, respectively. The algal biofuels produced include bio-oil $\left(E D_{B O}\right)$ and methane $\left(E D_{M}\right)$.

To evaluate the energy efficiency of the entire system shown in Figure 1, the $2^{\text {nd }} O$ EROI can be calculated for the combined wastewater treatment-algal biofuels system. For the combined wastewater treatment-algal biofuels system, the $2^{\text {nd }} O E R O I$ is calculated as

$$
\begin{aligned}
2^{\text {nd }} & \text { OEROI } \\
= & \frac{\left(\dot{E} D_{E}+\tilde{E}_{D H}\right) \cdot \frac{V_{W W}}{V_{P W}}+\left(\tilde{E}_{B O}+\tilde{E}_{M}\right)}{\left(\widetilde{E}_{P T}+\widetilde{E}_{S T}+\widetilde{E}_{S P}\right) \cdot \frac{V_{W W}}{V_{P W}}+\left(\widetilde{E}_{G}+\widetilde{E}_{P}+\widetilde{E}_{R}\right)}\left[\frac{k J / L_{P W}}{k J / L_{P W}}\right]
\end{aligned}
$$

where $V_{w w} / V_{P W}$ is the ratio of wastewater to processed water, which is 1.09 in this study for the independent operations and combined operations case.

\section{Results}

Independent Wastewater Treatment. The $2^{\text {nd }} O E R O I_{W W T}$ is calculated using eq 5 and the data listed in Table 1 as

$$
\begin{aligned}
& 2^{n d} O E R O I_{W W T}=\frac{{ }^{E} D_{E}+\dot{E}_{D H}}{\widetilde{E}_{P T}+\widetilde{E}_{S T}+\widetilde{E}_{S P}}=\frac{1.84+0.16}{0.16+4.80+0.48} \\
& =0.37\left[\frac{k J / L_{W W}}{k J / L_{W W}}\right]
\end{aligned}
$$

The energy requirement for secondary treatment dominates the energy input for the wastewater treatment plant. In particular, BNR accounts for $67 \%$ of the total energy input for wastewater treatment $\left(5.4 \mathrm{~kJ} / \mathrm{L}_{\mathrm{WwW}}\right)$, respectively. Much of the total energy input for wastewater treatment is from indirect energy associated with energy embedded in methanol for BNR (49\% of the total) and alum for BNR (5\% of the total).

Energy products from wastewater treatment include electricity produced by cogeneration, which provides for $1840 \mathrm{~J}$ of electricity per $L_{W w}$, and useful heat that is returned to the anaerobic digester (162 J of heat per $\mathrm{L}_{\mathrm{WWW}}$ ). The actual electricity yield from typical wastewater treatment facilities is typically lower than $1840 \mathrm{~J} / \mathrm{L}_{\mathrm{Ww}}$ (Stillwell et al., 2010), as considered in the sensitivity analysis in the following section.

Independent Algal Biofuel Production. The $2^{\text {nd }} O E R O I_{B F}$ is calculated using eq 6 and the data listed in Table 2 as

$$
\begin{aligned}
2^{\text {nd }} O E R O I_{B F} & =\frac{\dot{E} D_{B O}+\dot{E} D_{M}}{\widetilde{E}_{G}+\widetilde{E}_{P}+\widetilde{E}_{R}}=\frac{0.97+3.73}{7.88+2.66+0.52} \\
& =0.42\left[\frac{\mathrm{kJ} / L_{P W}}{\mathrm{~kJ} / L_{P W}}\right]
\end{aligned}
$$

The energy input for growth represents $71 \%$ of the total energy input for independent algal biofuel production; of this amount, energy embedded in $\mathrm{CO}_{2}$, energy embedded in nitrogen, and water supply energy represent $39 \%, 14 \%$, and $13 \%$ of the total energy input for algal biofuels production (11.0 $\left.\mathrm{kJ} / \mathrm{L}_{\mathrm{PW}}\right)$, respectively. Processing energy includes harvesting, water treatment and recycling, lysing, and separations, which contribute $20 \%, 1 \%, 0.3 \%$, and $2 \%$ of the total energy input, respectively. Energy required to pump algae to the harvesting facility represents $9 \%$ of the total energy input. Refining inputs account for $5 \%$ of the total energy input, and most of this energy is associated with methane refining ( $3 \%$ of the total energy input), which requires $10 \%$ of the methane produced from catalytic hydrothermal gasification.

The algal biofuels produced include bio-oil and methane. The productivity of these fuels is calculated by inserting productivity and efficiency values described previously into eqs 1 and 2 as

$$
\begin{aligned}
P_{B O} & =P_{G M} \cdot \varphi_{\text {harv }} \cdot \varphi_{\text {cellys }} \cdot \varphi_{\text {sep }} B C \cdot \varphi_{\text {ref }} B O \\
& =0.08 \cdot 0.95 \cdot 0.95 \cdot 0.09 \cdot 0.9=0.024\left[\frac{g}{L_{P W}-d}\right]
\end{aligned}
$$

and

$$
\begin{aligned}
P_{M} & =P_{G M} \cdot \varphi_{\text {harv }} \cdot \varphi_{\text {cellys }} \cdot \varphi_{\text {sep }} B S \cdot \varphi_{\text {ref }} M \\
& =0.08 \cdot 0.95 \cdot 0.95 \cdot 0.90 \cdot 0.25=0.068\left[\frac{g}{L_{P W}-d}\right]
\end{aligned}
$$

With 3.8 days of cultivation time, $v_{B O}=40 \mathrm{MJ} / \mathrm{kg}$, and $v_{B O}=40$ $M J / k g$ ), the energy yield of bio-oil and methane, per liter of processed water, is $970 \mathrm{~J} / \mathrm{L}_{\mathrm{PW}}$ and $3700 \mathrm{~J} / \mathrm{L}_{\mathrm{PW}}$, respectively. 
Aggregate Energy Return on Investment for Independent Operation of Wastewater Treatment and Algal Biofuel Production. In this section, the authors calculate an aggregate $2^{\text {nd }} O$ EROI for independent operation of both of the algal biofuel and wastewater treatment facilities that are termed the "aggregate" $2^{\text {nd }}$ O EROI. The aggregate $2^{\text {nd }} O$ EROI for the independent operation scenario can be calculated using data in Tables 1 and 2. For this calculation, the $2^{\text {nd }} O E R O I_{W W T}$ and $2^{\text {nd }}$ $O E R O I_{B F}$ are scaled according to the respective amounts of wastewater and processed water (as these volumes are not necessarily dependent on each other). As described previously in the section titled "Algal Cultivation", to provide a direct comparison with the combined wastewater treatment and algal biofuels production scenario, it was assumed that $1.09 \mathrm{~L}_{\mathrm{W} w \mathrm{~W}}$ is treated per $\mathrm{L}_{\mathrm{PW}}$ in the independent scenario. Therefore, using eq 7 and the aforementioned data, the aggregate $2^{\text {nd }} O E R O I$ for operating the WWTP and the algal biofuels production systems independently is

$$
\begin{aligned}
2^{\text {nd }} & \text { OEROI } I_{W W T \& B F} \\
= & \frac{\left(E_{E} D_{E}+E_{D H}\right) \cdot \frac{V_{W W}}{V_{P W}}+\left(\tilde{E}_{B O}+\tilde{E}_{M}\right)}{\left(\widetilde{E}_{P T}+\widetilde{E}_{S T}+\widetilde{E}_{S P}\right) \cdot \frac{V_{W W}}{V_{P W}}+\left(\widetilde{E}_{G}+\widetilde{E}_{P}+\widetilde{E}_{R}\right)} \\
= & \frac{(1.84+0.16) \cdot 1.09+(0.97+3.73)}{(0.16+4.80+0.48) \cdot 1.09+(7.88+2.66+0.52)} \\
= & 0.40\left[\frac{\mathrm{kJ} / L_{P W}}{\mathrm{~kJ} / L_{P W}}\right]
\end{aligned}
$$

Combined Wastewater Treatment and Algal Biofuel Production. Combining the wastewater treatment facility with algal biofuel production is advantageous for both systems, raising the $2^{N D} O E R O I$ for both wastewater treatment and algal biofuel production to be greater than 1 , as shown in Tables 3, 4, and 5. The $2^{N D} O E R O I$ of the combined system is 1.44 . Without the algal biofuels system, much of the embedded energy in wastewater (primarily nutrients) is wasted in the wastewater effluent or disposed of in solid waste, thus lowering the effective EROI of the overall society. With the algal biofuels system, some of that embedded energy is captured by recycling it to grow algae.

For wastewater treatment, an important benefit of using algal growth to clean water comes from the avoidance of other, more energy-intensive secondary treatment approaches. In addition, because there is less sludge produced in the combined scenario, the energy required for sludge treatment is cut by more than $75 \%$. As a result, the total energy required for the wastewater treatment processes is reduced from 5.4 to $0.28 \mathrm{~kJ} / \mathrm{L}_{\mathrm{www}}$. For algal biofuel production, the energy required for cultivating algae was reduced from 7.9 to $0.4 \mathrm{~kJ} / \mathrm{L}_{\mathrm{PW}}$, and most of this reduction is associated with the avoidance of consuming energy-intensive commercial forms of carbon, water, nitrogen, and phosphorus. The energy required for harvesting, discharge water treatment and recycling, lysing, separations, and refining is identical in the two scenarios because the growth volume is identical in each case.

The energy savings afforded in the combined system is partially offset by the reduction in electricity produced via cogeneration during wastewater treatment because there is no secondary sludge provided for anaerobic digestion. The electricity production was reduced from 1.8 to $0.7 \mathrm{~kJ} / \mathrm{L}_{\mathrm{www}}$. The amounts of bio-oil and methane produced from algae in the combined case are the same as those produced during independent algal biofuel production.

Net Operating Energy Impact to Existing Advanced Wastewater Treatment Plant. For existing plant operators, it is valuable to know what the net impact of installing an algal biofuels production system, like the one described in this study, would be on their existing WWTP. Based on the data presented previously, the second-order net operating energy impact $\left(2^{\text {nd }} \mathrm{O}\right.$ $N O E I$ ) can be calculated as

$$
2^{n d} O N O E I=\Delta \widetilde{E}_{W W T}+\Delta \widetilde{E}_{B F}-\Delta \dot{E}_{W W T}-\Delta E_{B F}\left[\frac{k J}{L_{P W}}\right]
$$

Where

$\Delta \widetilde{E}_{W W T}=$ the change in energy input required to operate wastewater treatment (a positive value corresponds to energy savings),

$\Delta \widetilde{E}_{B F}=$ the change in energy input required to operate the algal biofuels production pathway (evaluated between having no algal biofuels and the combined case),

$\Delta E D_{W W T}=$ the change in the energy output of the wastewater treatment facility (a positive number corresponds to a reduction in energy output), and

$\Delta E D_{B F}=$ the change in energy output from algal biofuels (evaluated between having no algal biofuels and the combined case).

Each of these terms is calculated as the difference between the energy produced or consumed by an advanced WWTP without an algal biofuels production system and the energy produced or consumed by the same WWTP integrated with algal biofuel production. Therefore, using data shown in Table 5,

$$
\begin{aligned}
2^{\text {nd }} O N O E I & =(6.0-0.3)+(0-3.6)-(2.2-0.9)-(0-4.7) \\
& =5.5\left[\frac{k J}{L_{P W}}\right]
\end{aligned}
$$

In other words, by adding the algal biofuels production system, $5.5 \mathrm{~kJ}$ of energy per $\mathrm{L}_{\mathrm{PW}}$ (equivalent to $5.0 \mathrm{~kJ} / \mathrm{L}_{\mathrm{W} w \mathrm{~W}}$ ) is produced or saved from a combination of energy input reductions and energy output increases, which were not previously available. If this productivity were achieved while integrating algae production and municipal wastewater treatment for all of the wastewater processed in the United States $\left(4.5 \times 10^{13} \mathrm{LWw} /\right.$ year [Christenson and Sims, 2011; U.S. EPA, 2008]), the result corresponds to a net energy effect of roughly $220 \mathrm{PJ} / \mathrm{yr}(220 \times$ $10^{15} \mathrm{~J} / \mathrm{yr}$ ), which is less than $0.3 \%$ of the United States' annual energy consumption.

\section{Sensitivity Analysis}

Nutrient Loading. This section presents a top-level assessment of the effect on $2^{\text {nd }} O E R O I_{W W T E B F}$ and $2^{\text {nd }} O$ NOEI if the nutrient concentration of the initial wastewater is varied. An equally important consideration is the relative amounts of carbon, nitrogen, and phosphorus in the wastewater. In the 
Table 5-Summary of energy consumption and production data for operating the WWTP and algal biofuels production system independently and as a combined system. The Net Impact to Existing Plant data are used to calculate the second-order net operating energy impact (NOEI) on a currently existing advanced wastewater treatment plant by adding the algal biofuel production system described in this study. Data are reported per liter of processed water, and the ratio of wastewater-to-processed water is 1.09.

\begin{tabular}{|c|c|c|c|}
\hline & $\begin{array}{l}\text { Independent systems } \\
\left(\mathrm{kJ} / \mathrm{L}_{\mathrm{PW}}\right)\end{array}$ & $\begin{array}{l}\text { Combined system } \\
\left(\mathrm{kJ} / \mathrm{L}_{\mathrm{PW}}\right)\end{array}$ & $\begin{array}{l}\text { Net Impact to existing plant } \\
\left(\mathrm{kJ} / \mathrm{L}_{\mathrm{PW}}\right)\end{array}$ \\
\hline \multicolumn{4}{|l|}{ Wastewater treatment input } \\
\hline Primary treatment $\tilde{E}_{P T}$ & 0.18 & 0.18 & 0.00 \\
\hline Secondary treatment w/ BNR $\tilde{E}_{S T}$ & 5.25 & 0.00 & 5.25 \\
\hline Sludge processing (primary and secondary) $\tilde{\tilde{E}}_{S P}$ & 0.53 & 0.12 & 0.40 \\
\hline Wastewater treatment total energy input $\tilde{E}_{W W T}$ & 5.95 & 0.30 & 5.65 \\
\hline \multicolumn{4}{|l|}{ Wastewater treatment output } \\
\hline Electricity from Co-Gen $E D_{E}$ & 2.02 & 0.81 & -1.21 \\
\hline Useful heat $E D_{D H}$ & 0.18 & 0.07 & -0.11 \\
\hline Wastewater treatment total energy output $E D_{W w T}$ & 2.19 & 0.88 & -1.32 \\
\hline \multicolumn{4}{|l|}{ Algal biofuels input } \\
\hline Growth $\tilde{E}_{G}$ & 7.88 & 0.40 & -0.40 \\
\hline Harvesting & 2.23 & 2.23 & -2.23 \\
\hline Water recycling and treatment & 0.16 & 0.16 & -0.16 \\
\hline Lysing & 0.03 & 0.03 & -0.03 \\
\hline Separations & 0.24 & 0.24 & -0.24 \\
\hline Refining $\tilde{E}_{R}$ & 0.52 & 0.52 & -0.52 \\
\hline Algal biofuels total energy input $\tilde{E}_{B F}$ & 11.06 & 3.58 & -3.58 \\
\hline \multicolumn{4}{|l|}{ Algal biofuels output } \\
\hline Bio-oil $E D_{B O}$ & 0.97 & 0.97 & 0.97 \\
\hline Methane $E D_{M}$ & 3.73 & 3.73 & 3.73 \\
\hline \multirow[t]{2}{*}{ Algal biofuels total energy output $E^{\prime} D_{B F}$} & 4.70 & 4.70 & 4.70 \\
\hline & Aggregate $2^{\text {nd }} 0$ EROI & Combined $2^{\text {nd }} 0$ EROI & \\
\hline Algal biofuels EROI, $2^{\text {nd }} O E R O I_{B F}$ & 0.42 & 1.31 & \\
\hline Wastewater EROI, $2^{\text {nd }} O$ EROI $W W T$ & 0.37 & 2.92 & \\
\hline \multirow[t]{3}{*}{ Scaled EROI, $2^{\text {nd }} O E R O I_{W W T \& B F}$} & 0.40 & 1.44 & \\
\hline & & $2^{\text {nd }} O \mathrm{NOEI}$ & $2^{\text {nd }} O$ NOEI \\
\hline & & $5.5 \mathrm{~kJ} / \mathrm{L}_{\mathrm{PW}}$ & $5.0 \mathrm{~kJ} / \mathrm{L}_{w w}$ \\
\hline
\end{tabular}

baseline analysis presented in the "Analysis" section, nitrogen was the limiting resource for algae growth and the amount of carbon and phosphorus was well-matched with the amount required. However, the nutrient content of wastewater is different for every wastewater treatment facility. The wastewater treatment processes and the algal cultivation process must be designed specifically for the particular wastewater composition available. For instance, if a wastewater source contains a disproportionately high amount of carbon, nitrogen, or phosphorus, specific processing methods would be required to remove that element as algal cultivation might not remove a

Table 6-Nutrient loading for the low, medium, and high nutrient cases.

\begin{tabular}{lcccc}
\hline Nutrient scenario & $\begin{array}{c}\mathbf{C} \\
\left(\mathbf{m g} / \mathbf{L}_{\mathbf{w w}}\right)\end{array}$ & $\begin{array}{c}\mathbf{N} \\
\left(\mathbf{m g} / \mathbf{L}_{\mathbf{w w}}\right)\end{array}$ & $\begin{array}{c}\mathbf{P} \\
\left(\mathbf{m g} / \mathbf{L}_{\mathbf{w w}}\right)\end{array}$ & $\begin{array}{c}\mathbf{C O D} \\
\left(\mathbf{m g} / \mathbf{L}_{\mathbf{w w}}\right)\end{array}$ \\
\hline $\begin{array}{l}\text { Low nutrient load } \\
\text { Medium nutrient load }\end{array}$ & 79 & 20 & 3.5 & 215 \\
$\begin{array}{l}\text { High nutrient load } \\
\text { C:N:P:BOD proportion } \\
\text { for all cases }\end{array}$ & 158 & 40 & 7 & 430 \\
\hline
\end{tabular}

* The nutrient loading of medium-strength wastewater was used as the baseline case in the "Results" section. sufficient amount of the element in excess to allow discharge to the environment. This type of plant alteration would require system redesign. As such, a single-parameter sensitivity analysis in which only one of the critical nutrients is varied is unfeasible.

Instead, three nutrient loadings are considered for the influent wastewater while maintaining the relative proportion of carbon, nitrogen, phosphorus, and COD that were used in the preceding analysis (which is 23:6:1:123). The three nutrient-loading scenarios that are considered are listed in Table 6 and the results for several key parameters are shown in Table 7. The low, medium, and high nutrient cases are similar to the low-, medium-, and high-strength nutrient loadings in typical domestic wastewater provided by Tchobanoglous et al. (2003). A key finding of this sensitivity analysis is that combined algal biofuel and wastewater treatment operation is more advantageous with higher nutrient loading, and, for the same growth rate, high nutrient loading requires a longer cultivation time for nutrient uptake.

Biomass Productivity and Lipid Content. Table 8 lists sensitivity analysis results for a series of grown mass productivities $(40,80$, and $160 \mathrm{mg} / \mathrm{L} \cdot \mathrm{d})$ and $\operatorname{NLF}(0.05,0.1$, and 0.2$)$. The results illustrate that the most advantageous scenario is one in which algal biomass productivity and NLF are maximized, as one would expect. However, the results also demonstrate that the $2^{\text {nd }} O$ EROI for this case $(160 \mathrm{mg} / \mathrm{L} \cdot \mathrm{d}$ and a NLF of 0.2$)$ is 
Table 7-Net operating energy impact (NOEI) results for low-, medium-, and high-strength nutrient loadings in wastewater.

\begin{tabular}{lccccccc}
\hline Nutrient loading & $\begin{array}{c}\text { Cult. time } \\
(\mathbf{d})\end{array}$ & $\begin{array}{c}\text { Ratio of wastewater } \\
\text { to processed water (-) }\end{array}$ & $\begin{array}{c}\text { Electricity } \\
\left(\mathbf{k J} / \mathbf{L}_{w w}\right)\end{array}$ & $\begin{array}{c}\text { Bio-oil } \\
\left(\mathbf{k J} / \mathbf{L}_{\mathbf{w w}}\right)\end{array}$ & $\begin{array}{c}\text { Methane } \\
\left(\mathbf{k J} / \mathbf{L}_{w w}\right)\end{array}$ & $\begin{array}{c}\text { Combined system } \\
\mathbf{2}^{\text {nd }} \mathbf{0} \text { EROI }\end{array}$ & $\begin{array}{c}\text { NOEI to existing plant } \\
\left(\mathbf{k J} / \mathbf{L}_{\text {ww }}\right.\end{array}$ \\
\hline Low & 1.90 & 1.05 & 0.37 & 0.44 & 1.70 & 0.90 & 4.08 \\
Medium* & 3.79 & 1.09 & 0.74 & 0.97 & 3.73 & 1.44 & 4.99 \\
High & 7.59 & 1.18 & 1.48 & 1.77 & 6.82 & 2.06 & 6.82 \\
\hline
\end{tabular}

* The nutrient loading of medium strength wastewater was used as the baseline case in the "Results" section.

only marginally better than the baseline case presented in the "Analysis" section $\left(80 \mathrm{mg} / \mathrm{L} \cdot \mathrm{d}\right.$, which is $16 \mathrm{~g} / \mathrm{m}^{2} \cdot \mathrm{d}$, and a lipid fraction of 0.1 ). Furthermore, the electricity, bio-oil, and methane productivity per $\mathrm{L}_{\mathrm{Ww}}$ are independent of the growth rate. This result occurs because all cases assume 100\% nitrogen uptake (which is the limiting resource) and, therefore, the algal density is only affected by the wastewater nutrient loading (see the section titled "Nutrient Loading"). The cultivation time (not listed) varies with grown mass productivity, and, therefore, for a particular nutrient loading, the scenario in which cultivation time is minimized (i.e., productivity is maximized) yields the highest $2^{\text {nd }} O E R O I$ and $2^{\text {nd }} O$ NOEI. This model assumes linear growth rates, although actual population dynamics may yield nonlinear effects.

Electricity Production from Cogeneration in Wastewater Treatment. The electricity production calculated in the "Analysis" section is based on general assumptions (i.e., 0.4 $\mathrm{m}^{3}$ methane/ $\mathrm{kg}$ COD and $30 \%$ electricity generation efficiency) that yield an electricity product of $1840 \mathrm{~J} / \mathrm{LWW}_{\mathrm{WW}}$ in independent operation (4.3 J/mg COD). Recently developed measurement methods suggest that municipal wastewater has an energy content of $7600 \mathrm{~J} / \mathrm{L}_{\mathrm{Ww}}$, yet only a fraction of this energy is feasibly recoverable (Heidrich et al., 2010). Actual electricity yields for wastewater treatment facilities are typically between 300 and $500 \mathrm{~J} / \mathrm{L}_{\mathrm{WWW}}$ (Burton, 1996; Stillwell et al., 2010; U.S. EPA, 2007). This result corresponds to an electricity yield of roughly 1 $\mathrm{J} / \mathrm{mg}$ of COD. In the combined system, the electricity yield is modeled as being reduced by $60 \%$ to $740 \mathrm{~kJ} / \mathrm{L}_{\mathrm{Ww}}$ because it is assumed that $60 \%$ of the COD is transferred to the algae ponds. Using this assumption, the electricity yield can be calculated for various COD-to-electricity conversions, as shown in Table 9. Reducing the electricity yield significantly affects the $2^{\text {nd }} O$ $E R O I_{W W T}$ because electricity is the main energy output from wastewater treatment. However, the $2^{\text {nd }} O E R O I_{W W T E B F}$ is relatively insensitive to the COD-to-electricity conversion because, for low conversion rates, the ratio becomes dominated by the energy input and energy output for the algal biofuels production pathway.

Biological Nutrient Removal Requirement. In the preceding analysis, it was assumed that BNR was required for the WWTP due to stringent effluent standards. However, in many locations, BNR is not currently required. For a WWTP in which BNR is not required, operating independently, the energy input for secondary treatment is reduced from $4.8 \mathrm{~kJ} / \mathrm{L}_{\mathrm{PW}}\left(4.4 \mathrm{~kJ} / \mathrm{L}_{\mathrm{WWW}}\right)$ to $1.2 \mathrm{~kJ} / \mathrm{L}_{\mathrm{PW}}\left(1.1 \mathrm{~kJ} / \mathrm{L}_{\mathrm{WWW}}\right)$. As a result, the $2^{\text {nd }} O E R O I_{W W T}$ in independent operation is increased from 0.37 to 1.10 . However, if $\mathrm{BNR}$ is not required, the energy savings that have been allocated to avoiding BNR will not apply. Thus, for combined algal biofuels and wastewater treatment operations in a scenario without a BNR requirement, the $2^{\text {nd }} O$ NOEI is also reduced from 5.0 to $1.4 \mathrm{~kJ} / \mathrm{L}_{\mathrm{WW}}$ (Table 5). For combined operations, the $2^{\text {nd }} O E R O I_{W W T E B F}$ is unaffected by the requirement of BNR, as BNR inputs are zero in that scenario.

Processing Efficiency and Energy Requirement. In the baseline case presented in the "Analysis" section, algal biomass processing, which includes harvesting, discharge water treatment and recycling, lysing, and separations, contributes $68 \%$ of the total energy input during the combined wastewater treatment and algal biofuels scenario (Table 5). Table 10 presents the effect on $2^{\text {nd }} O E R O I_{W W T E B F}$ and $2^{\text {nd }} O$ NOEI for the following three levels of processing energy inputs: (1) a baseline case that is the same as the data used for the combined scenario presented previously, (2) a less optimistic case that assumes all processing energy inputs are $200 \%$ of the baseline, and (3) a more optimistic scenario in which all processing inputs are $50 \%$ of the baseline. As shown, in the combined setting, the $2^{\text {nd }} O$ $E R O I_{W W T E B F}$ varies from 0.85 to 2.18 among these cases, which represents a range from energy-negative to energy-positive

Table 8-Energy return on investment (EROI) and net operating energy impact (NOEI) results for nine combinations of grown mass productivity and neutral lipid fraction.

\begin{tabular}{|c|c|c|c|c|c|c|c|c|}
\hline $\begin{array}{l}\text { Grown mass } \\
\text { productivity } \\
\text { (mg/L·d) }\end{array}$ & NLF (-) & $\begin{array}{c}\text { Ratio of WW } \\
\text { to PW }\end{array}$ & $\begin{array}{c}\text { Algal conc. at harvest } \\
(\mathrm{mg} / \mathrm{L})\end{array}$ & $\begin{array}{l}\text { Electricity } \\
\left(\mathrm{kJ} / \mathrm{L}_{w w}\right)\end{array}$ & $\begin{array}{c}\text { Bio-oil } \\
\left(k J / L_{w w}\right)\end{array}$ & $\begin{array}{l}\text { Methane } \\
\left(k J / L_{w w}\right)\end{array}$ & $\begin{array}{c}\text { Combined system } \\
2^{\text {nd }} 0 \text { EROI }\end{array}$ & $\begin{array}{l}\text { NOEI to existing plant } \\
\left(\mathrm{kJ} / \mathrm{L}_{\mathrm{ww}}\right)\end{array}$ \\
\hline \multirow[t]{3}{*}{40} & 0.05 & 1.18 & 300 & 0.74 & 0.44 & 3.60 & 1.32 & 4.62 \\
\hline & 0.1 & 1.18 & 300 & 0.74 & 0.89 & 3.41 & 1.37 & 4.83 \\
\hline & 0.2 & 1.18 & 300 & 0.74 & 1.77 & 3.03 & 1.47 & 5.23 \\
\hline \multirow[t]{3}{*}{$80^{*}$} & 0.05 & 1.09 & 300 & 0.74 & 0.44 & 3.60 & 1.38 & 4.78 \\
\hline & $0.1^{*}$ & 1.09 & 300 & 0.74 & 0.89 & 3.41 & 1.44 & 4.99 \\
\hline & 0.2 & 1.09 & 300 & 0.74 & 1.77 & 3.03 & 1.54 & 5.39 \\
\hline \multirow[t]{3}{*}{160} & 0.05 & 1.05 & 300 & 0.74 & 0.44 & 3.60 & 1.42 & 4.87 \\
\hline & 0.1 & 1.05 & 300 & 0.74 & 0.89 & 3.41 & 1.47 & 5.08 \\
\hline & 0.2 & 1.05 & 300 & 0.74 & 1.77 & 3.03 & 1.57 & 5.48 \\
\hline
\end{tabular}

* The baseline case presented assumed a grown mass productivity of $80 \mathrm{mg} / \mathrm{L} \cdot \mathrm{d}$ with a NLF of 0.1 . 
Table 9-Net operating energy impact (NOEI) results for various COD-to-electricity conversion efficiencies.

\begin{tabular}{|c|c|c|c|c|c|}
\hline $\begin{array}{l}\text { Electricity yield } \\
\text { ( } \mathrm{J} / \mathrm{mg} \mathrm{COD} \text { supplied } \\
\text { to digester) }\end{array}$ & $\begin{array}{l}\text { Electricity } \\
\left(\mathrm{kJ} / \mathrm{L}_{\mathrm{ww}}\right)\end{array}$ & $\begin{array}{l}\text { Wastewater treatment } \\
\text { combined system } \\
2^{\text {nd }} 0 \text { EROI }\end{array}$ & $\begin{array}{l}\text { Algae combined system } \\
2^{\text {nd }} 0 \text { EROI }\end{array}$ & $\begin{array}{l}\text { Combined system } \\
2^{\text {nd }} 0 \text { EROI }\end{array}$ & $\begin{array}{l}\text { NOEI to existing plant } \\
\left(\mathbf{k J} / \mathrm{L}_{w w}\right)\end{array}$ \\
\hline 1 & 0.16 & 0.81 & 1.31 & 1.27 & 4.41 \\
\hline 2.35 & 0.37 & 1.58 & 1.31 & 1.33 & 4.62 \\
\hline $4.7^{\star}$ & 0.74 & 2.92 & 1.31 & 1.44 & 4.99 \\
\hline
\end{tabular}

* The baseline case presented assumes $4.7 \mathrm{~J} / \mathrm{mg}$ of COD provided to anaerobic digestion.

operation. Similarly, the $2^{\text {nd }} O N O E I$ varies from $2.56 \mathrm{~kJ} / \mathrm{L}_{\mathrm{W} w \mathrm{w}}$ to $6.20 \mathrm{~kJ} / \mathrm{L}_{\mathrm{WW}}$ among these cases.

Experimental data for processing algae to bio-oil is not generally available. However, in a recent study by Beal et al. (2011a), the energy required for processing was $97 \mathrm{~kJ} / \mathrm{L}_{\mathrm{Ww}}$ (which would convert to $106 \mathrm{~kJ} / \mathrm{L}_{\mathrm{PW}}$ ) using the same type of technologies modeled in this study, as compared to $2.7 \mathrm{~kJ} / \mathrm{L}_{\mathrm{PW}}$ for processing required in the baseline case presented in the preceding "Analysis" section. Although those data were collected for a laboratory-scale, suboptimal production scenario, they demonstrate the advances that are needed in processing technology to enable profitable algal biofuel production, even in a combined operation with wastewater treatment.

Other Variables. There are several important variables in addition to the five aforementioned parameters. For instance, the energetic profitability of a wastewater treatment and algal biofuels facility will depend on the following:

- Relative nutrient loading in the wastewater (i.e., the proportion of carbon, nitrogen, phosphorus, and COD) and less-than-ideal nutrient uptake rates. It was assumed that $100 \%$ of the nitrogen and $100 \%$ of the carbon supplied to the pond was assimilated into biomass, while real cultures will have less-than-ideal uptake rates that will negatively affect the energy balance;

- Algal stoichiometry-it was assumed that the algal stoichiometry was constant, although it is known that algal biomass composition can be highly variable;

- Nonlinear algal growth conditions-linear productivity was assumed, although actual algal biomass productivity is typically linear for only a portion of the growth period; and

- Processing methods and efficiency-a variety of production techniques exist, and the specific system used will impact the overall EROI.

\section{Discussion}

This study sheds light on several important topics associated with energy evaluations of wastewater treatment and algal biofuel production. A few of the most pertinent of these topics include carbon dioxide emission effects, the potential for attached growth systems, effects on water consumption, the effect of producing high-value co-products from algae, and a comparison of the EROI of the combined wastewater treatment and algal biofuels system to conventional energy sources. Each of these topics is discussed in the following sections.

Carbon Dioxide Emissions. Coupling algal biofuel production with a wastewater treatment facility successfully avoids $\mathrm{CO}_{2}$ emissions from burning biogas produced by anaerobic digestion. Assuming that, absent of algal biofuel production, the same quantity of methane and oil would be produced and consumed from conventional sources, the net carbon effect can be compared between the following two scenarios: (1) independent operation of wastewater treatment and independent production and consumption of conventional methane and oil and (2) combined wastewater treatment and algal biofuel production. Only direct $\mathrm{CO}_{2}$ effects are considered in the following discussion, although secondary $\mathrm{CO}_{2}$ emissions (e.g., from electricity generation, materials production, etc.) can be important.

As stated in the "Analysis" section, $24 \mathrm{mg}$ of bio-oil (equivalent to $970 \mathrm{~J}$ ) and $68 \mathrm{mg}$ of methane (equivalent to $3700 \mathrm{~J}$ ) are produced per $\mathrm{L}_{\mathrm{PW}}$. Assuming algae-based methane and bio-oil are equivalent to their conventionally produced counterparts, combustion of these fuels produces $69 \mathrm{mg} \mathrm{CO} /$ $\mathrm{L}_{\mathrm{PW}}$ and $186 \mathrm{mg} \mathrm{CO}_{2} / \mathrm{L}_{\mathrm{PW}}$, respectively. For a WWTP that processes $1 \mathrm{mgd}$, with a wastewater-to-processed water ratio of 1.09 and carbon emissions of $0.0707 \mathrm{mg} \mathrm{CO} / \mathrm{J}$ of oil and 0.0503 $\mathrm{mg} \mathrm{CO}_{2} / \mathrm{J}$ of methane (U.S. EPA, 2007), these emissions correspond to 0.24 metric tons of $\mathrm{CO}_{2}$ per day from bio-oil and 0.65 metric tons $\mathrm{CO}_{2} / \mathrm{d}$ from methane. These $\mathrm{CO}_{2}$ emission rates are the same as those from equivalent quantities of conventionally produced fuels. However, independent wastewater treatment operation produces $540 \mathrm{mg} \mathrm{CO} 2 / \mathrm{L}_{\mathrm{WW}}$, or 2.04 metric tons $\mathrm{CO}_{2} / \mathrm{d}$ for $1 \mathrm{mgd}$ of wastewater, which is avoided during combined operation when the $\mathrm{CO}_{2}$ is used for algal cultivation. It is also important to consider $\mathrm{CO}_{2}$ used for algal cultivation during independent operations. However, a $100 \%$ $\mathrm{CO}_{2}$ uptake rate was assumed and the $\mathrm{CO}_{2}$ was not modeled as

Table 10-Energy return on investment (EROI) and net operating energy impact (NOEI) results for various algal biomass processing energy inputs.

\begin{tabular}{lcccccc}
\hline Scenario & $\begin{array}{c}\text { Harv. energy } \\
\left(\mathbf{k J} / \mathbf{L}_{\mathbf{P W}}\right)\end{array}$ & $\begin{array}{c}\text { DW treat. } \\
\left(\mathbf{k J} / \mathbf{L}_{\mathbf{P W}}\right)\end{array}$ & $\begin{array}{c}\text { Lysing energy } \\
\left(\mathbf{k J} / \mathbf{L}_{\mathbf{P W}}\right)\end{array}$ & $\begin{array}{c}\text { Sep. energy } \\
\left(\mathbf{k J} / \mathbf{L}_{\mathbf{P W}}\right)\end{array}$ & $\begin{array}{c}\text { Total proc. energy } \\
\left(\mathbf{k J} / \mathbf{L}_{\mathbf{P W}}\right)\end{array}$ & $\begin{array}{c}\mathbf{2}^{\text {nd }} \mathbf{0} \text { NOEI } \\
\left(\mathbf{k J} / \mathbf{L}_{\mathbf{W w}}\right)\end{array}$ \\
\hline Less optimistic & 4.45 & 0.33 & 0.06 & 0.47 & 5.31 & 0.85 \\
Baseline $^{*}$ & 2.23 & 0.16 & 0.03 & 0.24 & 2.66 & 2.56 \\
Most optimistic & 1.11 & 0.08 & 0.02 & 0.12 & 1.33 & 2.99 \\
\hline
\end{tabular}

* The baseline case presented uses the data shown for the baseline case presented here. 
being collected from an emissions source. As a result, the independent algal biofuels scenario does not produce or prevent carbon dioxide emissions. Thus, emissions from algal cultivation, methane combustion, and oil combustion are the same between the two scenarios, while the combined wastewater treatment and algal biofuel production scenario avoids $540 \mathrm{mg}$ $\mathrm{CO}_{2} / \mathrm{L}_{\mathrm{WW}}$ (or 2.04 metric tons $\mathrm{CO}_{2} / \mathrm{d}$ ) from co-generation.

If the $\mathrm{CO}_{2}$ emissions savings associated with using cogeneration flue gas for algal cultivation were accomplished for all of the wastewater processed in the United States $\left(4.5 \times 10^{13} \mathrm{~L}_{\mathrm{ww}} /\right.$ yr [Christenson and Sims, 2011; U.S. EPA, 2008]), $24.3 \times 10^{6}$ metric tons of $\mathrm{CO}_{2}$ emissions would be avoided annually. This $\mathrm{CO}_{2}$ avoidance rate represents only approximately $0.5 \%$ of the total $\mathrm{CO}_{2}$ emissions in the United States $\left(5.44 \times 10^{9}\right.$ metric tons/ yr [Hockstad and Cook, 2011]), but, in the presence of a $\mathrm{CO}_{2}$ emissions penalty on the order of $\$ 10$ to $\$ 100 /$ metric ton of $\mathrm{CO}_{2}$, these avoided $\mathrm{CO}_{2}$ emissions could cut costs for a 1-mgd facility by several thousands to tens of thousands of U.S. dollars per year.

Attached Growth. Ozkan et al. (2010) reported the operation and evaluation of a novel photobioreactor based on cultivating algae as biofilms on surfaces. This concept eliminated the need for mixing and can produce direct algal biomass concentrations of more than $90 \mathrm{~g} / \mathrm{L}$, eliminating the need for pumping dilute suspensions and primary dewatering (flocculation and deflocculation). Moreover, the algae are decoupled from the wastewater stream as attached cells on surfaces, thus virtually eliminating the need for water recycling and the energy cost associated with these processes and further increasing the EROI of the system. Although algal biofilm reactors are in their infancy at the moment and suffer from lower biomass productivity, under laboratory conditions photosynthetic efficiencies as large as $2 \%$ have been demonstrated and are expected to be further improved with research and development (Christenson and Sims, 2011; Ozkan et al., 2010; Ozkan et al., 2012).

Water Use Effects. An area worthy of further analysis raised by this work is that of water intensity of transportation, defined as the amount of water used in producing fuel per distance traveled. It has been reported that algal biofuels have a water intensity that is orders of magnitude greater than that of fossil fuels (Beal, 2011). The combination of algal growth and wastewater treatment underscores the key role in defining boundaries for such analyses. For example, in the combined operation scenario, where wastewater effluent is used to cultivate algae, a minimal amount of freshwater is consumed for producing biofuel from algae. As a result, the direct (fresh) water intensity of transportation from these fuels would be quite low. There are additional water effects associated with indirect water use (e.g., water used to produce electricity that is consumed), which need to be considered. Further work is needed to unambiguously attribute water usage in the combined facility.

Co-Products. Microalgae can be used for the production of a range of nonfuel high-value co-products for use in nutraceutical, pharmaceutical, and cosmetic spaces and as livestock feed and biofertilizers. Most algal fuel companies are increasingly focusing on these high-end nonfuel products for key addressable markets first, and then plan to gradually shift to fuel production as more breakthroughs occur in the algae fuel industry. Commonly targeted co-products include omega fatty acids, proteins, and carotenoids such as $\beta$-carotene and lutein (Blanco et al., 2007; Lipstein et al., 1980; Shelef, 1982; Subhadra and Edwards, 2011). In the United States, about 11.3 billion killograms of nitrogen and 1.8 billion killograms of phosphorus are applied as fertilizer annually (Huang, 2007) over a cropland area of roughly 330 million acres $\left(1.3 \times 10^{12} \mathrm{~m}^{2}\right)$ (Lubowski et al., 2006). Based on a grown mass productivity of $16 \mathrm{~g} / \mathrm{m}^{2} \cdot \mathrm{d}$, a biomass nitrogen content of $9 \%$, and a biomass phosphorus content of $1 \%, 21 \times 10^{9} \mathrm{~m}^{2}$ (5.2 million acres) of algae ponds are needed to fulfill the U.S. nitrogen fertilizer demand and $30 \times 10^{9}$ $\mathrm{m}^{2}$ (7.4 million acres) of algae ponds are needed to fulfill the U.S. phosphorus fertilizer demand. In addition, crops may absorb nutrients from algal biomass more easily than from industrial fertilizers.

Algae contain a high protein content (e.g., up to 50\% in algae grown in wastewater [Shelef, 1982]), which is valuable for animal feed. Some experiments suggest that algal biomass is fungible with soy meal animal feed (Lipstein et al., 1980). Carotenoids (i.e., xanthophylls) are high-value products that are currently used as fish, shrimp, and poultry feed ingredients. These compounds have tremendous potential as pharmaceutical and nutraceutical products. Lutein is prevalent in a wide variety of open-pond algal species (Blanco et al., 2007); is used in drugs, cosmetics, and as a feed substitute; and has an annual market value of $\$ 150$ million (U.S. dollars) (Jin et al., 2003). Other highvalue products produced by algae include astaxanthin, $\beta$ carotene, and omega fatty acids. However, the production and recovery of these products has yet to be proven in open-pond and/or wastewater environments.

Comparing the Energy Return on Investment for Wastewater Treatment and Algal Biofuels to other Fuels. The $2^{\text {nd }} O$ $E R O I_{W W T E B F}$ values calculated in this study represent only a portion of the supply chain inputs required to run a business producing fuels from algae. It is important to place the EROI calculations in the context of other competing fuels, particularly liquid fuels. Figure 2 summarizes calculations from several EROI studies of liquid fuels, including the United States' oil and gas production (Cleveland, 2005; Guilford et al., 2011), delivered gasoline (King, 2010), Brazilian sugar cane ethanol (Macedo et al., 2008), and the United States' corn ethanol (Farrell et al., 2006).

The results in Figure 2 display how EROI calculations compare when considering the following four analytical boundaries: (1) direct energy inputs only; (2) direct and indirect energy inputs; (3) direct, indirect, and capital inputs; and (4) all required expenses. For a given energy source, the energy output (i.e., numerator in the EROI calculation) is the same across these four boundaries. However, the energy input (i.e., the denominator in the EROI calculation) varies across these boundaries. In most of the literature in which analysts report EROI, only a single value is reported. Unfortunately, this practice obscures much of the richness of the calculation, particularly the boundary chosen for the EROI calculation, and does not clarify how to interpret the EROI value in light of the rest of the literature. In addition, few life-cycle analysis studies present an EROI value that is readily comparable to the boundary of operating an entire business, which includes paying salaries, taxes, interest on debt, and so on. To make the EROI metric more relevant for both policy and industry decision-making, it is useful to understand EROI in terms of the full business supply chain (Henshaw et al., 2011; King et al., 2010). 
Oil and gas production has historically had a direct energy EROI ( $1^{\text {st }} O$ EROI) over 24 . By the time oil is refined into fuels such as gasoline and sold at the gas pump, the EROI is typically between 4 and 8 . To make a comparison with algal biofuel production, we can first consider the embodied energy input for the industrial capital of an algal biofuel production facility. The associated EROI will be lower than the $2^{\text {nd }} O$ EROI presented previously. Recent techno-economic analyses of algal biofuel production systems similar to that evaluated in this study demonstrate that capital costs are expected to be roughly $50 \%$ of the total cost (Davis et al., 2011; Lundquist et al., 2010). By assuming that industrial capital accounts for approximately half of the total embodied energy input of physical materials and energy, the corresponding EROI of the integrated wastewater treatment and algal biofuel facility lowers to near 0.75 , with the independent algal biofuels facility having an EROI of $\sim 0.25$, as shown in Figure 2. Including all inputs required for providing delivered algal biofuels, to enable direct comparison with delivered gasoline, would further reduce the associated EROI.

In short, both corn-ethanol and algal biofuels produced from wastewater have a lower EROI at the beginning of the supply chain than conventional petroleum gasoline has at the end of the oil supply chain. However, fossil fuel supplies are not destined to have high EROI because the existing marginal source of oil (i.e., Canadian oil sands) has a low $1^{\text {st }} O$ EROI of 3 to 6 when produced using the Steam Assisted Gravity Discharge method (Smil, 2008). In addition, U.S. oil shale deposits represent a large resource with even lower EROI values of 1.2 to 1.6 for in situ production when including direct and indirect capital energy (Brandt, 2008). Because low EROI has been correlated to the recession (King, 2010), careful consideration of the EROI for alternative energy sources is important for policy makers.

\section{Conclusions and Limitations}

With conventional, independently operated systems, algal biofuel production requires significant inputs of nitrogen, phosphorus, carbon dioxide, and water, all of which require energy directly and indirectly; in addition, the WWTPs require significant energy inputs for treatment of the waste streams. However, by combining the two, energy inputs can be significantly reduced because outputs from one system can serve as the inputs for the other. Consequently, the energy balances for the integrated system can significantly outperform those from the isolated system.

There are several conclusions that can be drawn from this analysis. First, the $2^{\text {nd }} O E R O I$ was determined for both the WWTP and biofuels production process (operating in isolation from each other), and was found to be 0.37 and 0.42 , respectively. Thus, for this benchmark in conventional operation, both systems are operating as energy sinks.

Second, coupling wastewater treatment and algal biofuel production is mutually beneficial, and the extent of those benefits was quantified through $2^{\text {nd }} O E R O I$ analysis of the integrated system. As a result, two energy sinks from the isolated systems are converted to a combined energy source for the integrated system, with $2^{\text {nd }} O E R O I_{W W T E B F}=1.44$. This mutually beneficial scenario corresponds to an energy savings (or production) of roughly $5.5 \mathrm{~kJ} / \mathrm{L}_{\mathrm{PW}}$ (equivalent to $5.0 \mathrm{~kJ} /$ $\mathrm{L}_{\mathrm{Ww}}$ ). In the independent case, wastewater required $6.0 \mathrm{~kJ} / \mathrm{L}_{\mathrm{PW}}$; therefore, this energy savings and production represents an offset of nearly the entire operating energy cost of wastewater treatment. Applying this result for all the wastewater processed in the United States $\left(4.5 \times 10^{13} \mathrm{~L}_{W w} / \mathrm{yr}\right.$ [Christenson and Sims, 2011; U.S. EPA, 2008]) corresponds to a net energy effect of roughly $220 \mathrm{PJ} / \mathrm{yr}\left(220 \times 10^{15} \mathrm{~J} / \mathrm{yr}\right)$. While this represents less than $1 \%$ of the United States' annual energy consumption, it is still significant enough to be relevant.

Although this integrated system (for which many of the most expensive and energy-intensive inputs are provided for "free") represents one of the most advantageous scenarios for producing algal biofuels production, at 1.31 , the $2^{\text {nd }} O E R O I_{B F}$ is just barely a net-energy producer. Thus, this analysis simultaneously illustrates some of the opportunities and remaining challenges for algal biofuels production. While the combined case already contains optimistic assumptions, increases in the nutrient loading in wastewater, biomass productivity, and lipid productivity and decreases in the processing energy requirement would enable additional improvements, as shown in the sensitivity analysis. However, none of the results that were considered yielded a $2^{\text {nd }} O E R O I_{W W T E B F}>2.2$.

It is also important to note the limitations of this study. First, the results presented here apply only to the specific wastewater treatment and algal biofuels production system considered. There are several variations of the wastewater treatment and algal biofuels system modeled in this study and countless additional processes that could have been used (for both wastewater treatment and algal biofuel production). In practice, each WWTP and each algal biofuel production system will be different; thus, the energy implications of coupling wastewater treatment with algal biofuel production should be considered on a case-by-case basis. That is, because each waste stream and integrated system design is different, these quantitative results should not be considered universally applicable. However, it is expected that the methodology and analytical approach laid out in this study are transferrable and will be valuable for assessing other integrated configurations and waste streams.

In addition, the scenario modeled in this study is extremely optimistic (e.g., efficient electricity generation from biogas, efficient growth and processing methods for algal biofuel production, $16 \mathrm{~g} / \mathrm{m}^{2} \cdot \mathrm{d}$ of algal biomass productivity, $10 \%$ neutral lipid content, $100 \%$ nutrient uptake rates, etc.). For firstgeneration wastewater treatment and algal biofuel systems, energy consumption is expected to be greater than that modeled here and energy production is expected to be lower than that modeled here. In addition, this study does not consider the capital cost implications of implementing a combined wastewater treatment and algal biofuel production system, and the capital costs for such a scenario are expected to be high. Despite those limitations, this work does provide a valuable baseline for comparison. Furthermore, while the specific processes that are modeled and associated data should be tailored to each unique system, this work provides the methodology for analyzing those differences via the second-order EROI for a combined wastewater treatment and algal biofuel production system.

\section{Abbreviations and Nomenclature}

$$
\begin{aligned}
\mathrm{BNR} & =\text { Biological nutrient removal } \\
\mathrm{WW} & =\text { Wastewater } \\
\mathrm{WWT} & =\text { Wastewater treatment } \\
\mathrm{PE} & =\text { Primary effluent }
\end{aligned}
$$


PW = Processed water (i.e., algal growth volume processed for biofuel production)

$1^{\text {st }}$ O EROI $=$ First-order energy return on investment

$2^{\text {nd }} O E R O I=$ Second-order energy return on investment

$P=$ Productivity

$V=$ Volume

$\varphi=$ Efficiency

$E=$ Energy inputs

$E D=$ Direct energy outputs

$t_{c}=$ Cultivation time

$v=$ Energy content (in units of joules per kilogram)

$d=$ Pond depth (in units of meters)

\section{Products:}

$$
\begin{aligned}
\mathrm{AC} & =\text { Algal Concentrate } \\
\mathrm{BO} & =\text { Bio-oil } \\
\mathrm{GM} & =\text { Grown mass } \\
\mathrm{M} & =\text { Methane } \\
\mathrm{BF} & =\text { Biofuel } \\
\mathrm{BS} & =\text { Biomass in slurry } \\
\mathrm{BC} & =\text { Biocrude } \\
\mathrm{DH} & =\text { Anaerobic digester heat }
\end{aligned}
$$

\section{Wastewater Treatment Processes:}

$$
\begin{aligned}
& \mathrm{PT}=\text { Primary treatment } \\
& \mathrm{ST}=\text { Secondary treatment } \\
& \mathrm{SP}=\text { Sludge processing }
\end{aligned}
$$

\section{Algal Biofuels Production Processes:}

$$
\begin{aligned}
\mathrm{G} & =\text { Growth } \\
\mathrm{P} & =\text { Processing } \\
\mathrm{R} & =\text { Refining } \\
\mathrm{H} & =\text { Harvesting } \\
\mathrm{CL} & =\text { Cell lysing } \\
\mathrm{D} & =\text { Distribution }
\end{aligned}
$$

\section{Efficiency:}

$$
\begin{aligned}
\text { Harv } & =\text { Harvesting } \\
\text { Cellys } & =\text { Cell lysing } \\
\text { Sep } & =\text { Separations } \\
\text { Proc } & =\text { Processing } \\
\text { Ref } & =\text { Refining }
\end{aligned}
$$

\section{Composition:}

$$
N L F=\text { Neutral lipid fraction }
$$

\section{Accents:}

$\tilde{X}=$ Tilde denotes an input for a processing step

$\dot{X}=$ Apostrophe indicates units of joules per liter of processed volume

\section{Acknowledgments}

We would like to thank the entire algal biofuels research team at the University of Texas at Austin for collaboration on this research and OpenAlgae LLC for financial support. In particular, we would like to acknowledge A.F. Seibert, P. Palmer, L. Katz, K.
Kinney, and J. Choi. We would also like to thank J. Oyler of Genifuel for providing data regarding methane production.

Submitted for publication March 29, 2012; accepted for publication August 24, 2011.

\section{References}

Amin, S. (2009) Review on Biofuel Oil and Gas Production Processes from Microalgae. Energy Conversion Manage., 50, 1834-1840.

Arpke, A.; Hutzler, N. (2006) Domestic Water Use in the United States: A Life-Cycle Approach. J. Ind. Ecol., 10, 169-184.

Batan, L.; Quinn, J.; Willson, B.; Bradley, T. (2010) Net Energy and Greenhouse Gas Emission Evaluation of Biodiesel Derived from Microalgae. Environ. Sci. Technol., 44, 7975-7980.

Beal, C. M. (2011) Constraints on Algal Biofuel Production. Mechanical Engineering, Doctoral Dissertation, University of Texas at Austin, Austin, Texas. http://repositories.lib.utexas.edu/handle/2152/ ETD-UT-2011-05-2775.

Beal, C. M.; Hebner, R. E.; Webber, M. E.; Ruoff, R. S.; Seibert, A. F. (2011a) The Energy Return on Investment for Algal Biocrude: Results for a Research Production Facility. BioEnergy Res., 1-22.

Beal, C.M.; Hebner, R.E.; Webber, M.E.; Ruoff, R.S. (2012) First-Principles Thermodynamic Analysis of Algal Biocrude Production. Energy, In press.

Beal, C. M.; Smith, C. H.; Webber, M. E.; Ruoff, R. S.; Hebner, R. E. (2011b) A Framework to Report the Production of Renewable Diesel from Algae. BioEnergy Res., 4, 36-60.

Blanco, A. M.; Moreno, J.; Del Campo, J. A.; Rivas, J.; Guerrero, M. G. (2007) Outdoor Cultivation of Lutein-Rich Cells of Muriellopsis sp. in Open Ponds. Applied Microbiol. Biotechnol., 73, 1259-66.

Börjesson, P. I. I. (1996) Energy Analysis of Biomass Production and Transportation. Biomass and Bioenergy, 11, 305-318.

Brandt, A. R. (2008) Converting Oil Shale to Liquid Fuels: Energy Inputs and Greenhouse Gas Emissions of the Shell In Situ Conversion Process. Environ. Sci. Technol., 42, 7489-7495.

Brennan, L.; Owende, P. (2010) Biofuels from Microalgae-A Review of Technologies for Production, Processing, and Extractions of Biofuels and Co-Products. Renewable Sustainable Energy Rev., 14, 557-577.

Burton, F. L. (1996) Water and Wastewater Industries: Characteristics and Energy Management Opportunities; CR-106941; Electric Power Research Institute Community Environmental Center: Palo Alto, California.

Campbell, P. K.; Beer, T.; Batten, D. (2010) Life Cycle Assessment of Biodiesel Production from Microalgae in Ponds. Bioresour. Technol., 102, 50-56.

Capello, C.; Fischer, U.; Hungerbuhler, K. (2007) What Is a Green Solvent? A Comprehensive Framework for the Environmental Assessment of Solvents. Green Chem., 9, 927-934.

Choi, J. (2009) Pilot Scale Evaluation of Algae Harvesting Technologies for Biofuel Production, Masters Thesis, University of Texas at Austin, Austin, Texas.

Christenson, L.; Sims, R. (2011) Production and Harvesting of Microalgae for Wastewater Treatment, Biofuels, and Bioproducts. Biotechnol. Adv., 29 (6), 686-702

Clarens, A. F.; Resurreccion, E. P.; White, M. A.; Colosi, L. M. (2010) Environmental Life Cycle Comparison of Algae to Other Bioenergy Feedstocks. Environ. Sci. Technol., 44, 1813-1819.

Cleveland, C. J. (2005) Net Energy from the Extraction of Oil and Gas in the United States. Energy, 30, 769-782.

Collet, P.; Helias, A.; Lardon, L.; Ras, M.; Goy, R.; Steyer, J. (2011) LifeCycle Assessment of Microalgae Culture Coupled to Biogas Production. Bioresour. Technol., 102, 207-214.

Connelly, R.; Davey, K.; Pratap, S.; Uglum, J.; Werst, M.; Hebner, R. (In Preparation) Pulsed Electric Field Lysing of Algal Cells. 
Davis, R.; Aden, A.; Pienkos, P. T. (2011) Techno-Economic Analysis of Autotrophic Microalgae for Fuel Production. Appl. Energy, 88, 3524-3531.

Farrell, A. E.; Plevin, R. J.; Turner, B. T.; Jones, A. D.; O’Hare, M.; Kammen, D. M. (2006) Ethanol Can Contribute to Energy and Environmental Goals. Science, 311, 506-508.

Fleischer, E. J.; Broderick, T. A.; Daigger, G. T.; Fonseca, A. D.; Holbrook, R. D.; Murthy, S. N. (2005) Evaluation of Membrane Bioreactor Process Capabilities to Meet Stringent Effluent Nutrient Discharge Requirements. Water Environ. Res., 77, 162-178.

Goldstein, R.; Smith, W. (2002) Water \& Sustainability (Vol. 4): U.S. Electricity Consumption for Water Supply \& Treatment; EPRI \#1006787; Electric Power Research Institute: Palo Alto, California.

Guilford, M. C.; Hall, C. A. S.; Cleveland, C. J. (2011) A New Long Term Assessment of EROI for U.S. Oil and Gas Production Sustainability, 3, 1866-1887.

Hall, C. A. S.; Cleveland, C. J.; Kaufmann, R. K. (1984) Energy and Resource Quality: The Ecology of the Economic Process; Wiley \& Sons: New York.

Heidrich, E. S.; Curtis, T. P.; Dolfing, J. (2010) Determination of the Internal Chemical Energy of Wastewater. Environ. Sci. Technol., 45, 827-832.

Henshaw, P.; King, C. W.; Zarnikau, J. (2011) System Energy Assessment (SEA), Defining a Standard Measure of EROI for Energy Businesses as Whole Systems. Sustainability, 3, 1908-1943.

Hockstad, L.; Cook, B. (2011) 2011 Draft U.S. Greenhouse Gas Inventory Report. http://www.epa.gov/climatechange/emissions/usinventoryreport. html.

Huang, G.; Chen, F.; Wei, D.; Zhang, X.; Chen, G. (2010) Biodiesel Production by Microalgal Biotechnology. Appl. Energy, 87, 38-46.

Huang, W. (2007) Impact of Rising Natural Gas Prices on U.S. Ammonia Supply; Report WRS-0702; U.S. Department of Agriculture, Economic Research Service: Washington, D.C.

Jin, E.; Polle, J.; Lee, H.; Jun, S.; Chang, M. (2003) Xanthophylls in Microalgae, from Biosynthesis to Biotechnological Mass Production and Applications. J. Microbiol. Biotechnol., 13, 165-174.

Kim, S.; Overcash, M. (2003) Energy in Chemical Manufacturing Processes: Gate-to-Gate Information for Life Cycle Assessment. J. Chem. Technol. Biotechnol., 78, 995-1005.

King, C. W. (2010) Energy Intensity Ratios as Net Energy Measures of United States Energy Production and Expenditures. Environ. Res. Lett., 5.

King, C. W.; Holman, A. S.; Webber, M. E. (2008) Thirst for Energy. Nature Geoscience, 1, 283-286.

King, C. W.; Zarnikau, J.; Henshaw, P. (2010) Defining a Standard Measure for Whole System EROI Combining Economic "TopDown" and LCA "Bottom-up" Accounting. In ASME ES2010, Proceedings of the $4^{\text {th }}$ International Conference on Energy Sustainability; Phoenix, Arizona.

Klara, J. M. (2007) Cost Performance Baseline for Fossil Energy Plants: Bituminous Coal and Natural Gas to Electricity; National Energy Technology Laboratory: Morgantown, West Virginia.

Knuckey, R. M.; Brown, M. R.; Robert, R.; Frampton, D. M. F. (2006) Production of Microalgal Concentrates by Flocculation and their Assessment as Aquaculture Feeds. Aquacultural Eng., 35, 300-313.

Kubiszewski, I.; Cleveland, C. J.; Endres, P. K. (2010) Meta-Analysis of Net Energy Return for Wind Power Systems. Renewable Energy, 35, 218-225.

Lardon, L.; Helias, A.; Sialve, B.; Steyer, J.; Bernard, O. (2009) Life-Cycle Assessment of Biodiesel Production from Microalgae. Environ. Sci. Technol., 43, 6475-6481.

Lipstein, B.; Hurwitz, S.; Bornstein, S. (1980) The Nutritional Value of Algae for Poultry. Dried Chlorella in Layer Diets. British Poultry Sci., 21, 23-27.
Lubowski, R. N.; Bucholtz, S.; Claassen, R.; Roberts, M. J.; Cooper, J. C.; Gueorguieva, A.; Johansson, R. (2006) Environmental Effects of Agricultural Land-Use Change: The Role of Economics and Policy; No. ERR-25; U.S. Department of Agriculture, Economic Research Service: Washington, D.C.

Lundquist, T. J.; Woertz, I. C.; Quinn, N. W. T.; Benemann, J. R. (2010) A Realistic Technology and Engineering Assessment of Algae Biofuel Production; Energy Biosciences Institute: Berkeley, California.

Macedo, I. C.; Seabra, J. E. A.; Silva, J. E. A. R. (2008) Green House Gases Emissions in the Production and Use of Ethanol from Sugarcane in Brazil: The 2005/2006 Averages and a Prediction for 2020. Biomass and Bioenergy, 32, 582-595.

Molina Grima, E.; Belarbi, E. H.; Acién Fernández, F. G.; Robles Medina, A.; Chisti, Y. (2003) Recovery of Microalgal Biomass and Metabolites: Process Options and Economics. Biotechnol. Adv., 20, 491-515.

Mulder, K.; Hagens, N. J. (2009) Energy Return on Investment: Toward a Consistent Framework. AMBIO: J. Human Environ., 37, 74-79.

Murphy, C. (2010) Analysis of Innovative Feedstock Sources and Production Technologies for Renewable Fuels: Chapter 6. Algal Oil Biodiesel; EPA XA-83379501-0; University of Texas at Austin: Austin, Texas.

Oyler, J. (2010) Genifuel: Catalytic Hydrothermal Gasification. Personal communication with C. M. Beal.

Ozkan, A.; Kinney, K.; Katz, L.; Berberoglu, H. (2010) Novel Biofilm Photobioreactor for Minimizing Energy and Water Requirements of Algae Cultivation; IMECE2010-39621; Proceedings of ASME International Mechanical Congress and Exposition; Vancouver, British Columbia, Canada.

Ozkan, A.; Kinney, K.; Katz, L.; Berberoglu, H. (2012) Reduction of Water and Energy Requirement of Algae Cultivation Using an Algae Biofilm Photobioreactor. Bioresour. Technol., 114, 542-548.

Park, J. B. K.; Craggs, R. J. (2011) Algal Production in Wastewater Treatment High Rate Algal Ponds for Potential Biofuel Use. Water Sci. Technol., 63, 2403-2410.

Park, J. B. K.; Craggs, R. J.; Shilton, A. N. (2010) Wastewater Treatment High Rate Algal Ponds for Biofuel Production. Bioresour. Technol., 102, 35-42.

Parker, D. S. (2011) Introduction of New Process Technology into the Wastewater Treatment Sector. Water Environ. Res., 83, 483-497.

Pate, R.; Klise, G.; Wu, B. (2011) Resource Demand Implications for U.S. Algae Biofuels Production Scale-Up. Appl. Energy, 88, 3377-3388.

Pittman, J. K.; Dean, A. P.; Osundeko, O. (2011) The Potential of Sustainable Algal Biofuel Production Using Wastewater Resources. Bioresour. Technol., 102, 17-25.

Ramírez, C. A.; Worrell, E. (2006) Feeding Fossil Fuels to the Soil: An Analysis of Energy Embedded and Technological Learning in the Fertilizer Industry. Resour. Conserv. Recycling, 46, 75-93.

Ryder, R.; de Boer, A. (2009) Dechlorination Chemical Options and Considerations. Proceedings of the Water Environment Federation; pp 516-522.

Schenk, P.; Thomas-Hall, S.; Stephens, E.; Marx, U.; Mussgnug, J.; Posten, C.; Kruse, O.; Hankamer, B. (2008) Second Generation Biofuels: High-Efficiency Microalgae for Biodiesel Production. BioEnergy Res., 1, 20-43.

Shapouri, H.; Duffield, J.; Wang, M. (2002) The Energy Balance of Corn Ethanol: An Update; USDA Agricultural Economic Report No. 814; U.S. Department of Agriculture: Washington, D.C.

Sheehan, J.; Camobreco, V.; Duffield, J.; Shapouri, H.; Graboski, M.; Tyson, K. S. (2000) An Overview of Biodiesel and Petroleum Diesel Life Cycles; NREL/TP-580-24772; National Renewable Energy Laboratory: Golden, Colorado.

Sheehan, J.; Dunahay, T.; Benemann, J.; Roessler, P. (1998) A Look Back at the U.S. Department of Energy's Aquatic Species Program, Biodiesel from Algae; NREL/TP-580-24190; National Renewable Energy 
Laboratory and U.S. Department of Energy, Office of Fuels Development: Golden, Colorado.

Shelef, G. (1982) High-Rate Algae Ponds for Wastewater Treatment and Protein Production. Water Sci. Technol., 14, 439-452.

Smil, V. (2008) Energy in Nature and Society: General Energetics of Complex Systems; The MIT Press: Cambridge, Massachusetts.

Stillwell, A. S.; Hoppock, D. C.; Webber, M. E. (2010) Energy Recovery from Wastewater Treatment Plants in the United States: A Case Study of the Energy-Water Nexus. Sustainability, 2, 945-962.

Sturm, B. S. M.; Lamer, S. L. (2011) An Energy Evaluation of Coupling Nutrient Removal from Wastewater with Algal Biomass Production. Appl. Energy, 88, 3499-3506.

Subhadra, B. G.; Edwards, M. (2011) Coproduct Market Analysis and Water Footprint of Simulated Commercial Algal Biorefineries. Appl. Energy, 88, 3515-3523.

Tchobanoglous, G.; Burton, F.L.; Stensel, H.D. (2003) Wastewater Engineering: Treatment and Reuse. Metcalf \& Eddy Inc., McGraw Hill.

U.S. Environmental Protection Agency (2008) Clean Watersheds Needs Survey 2008 Report to Congress. http://water.epa.gov/scitech/ datait/databases/cwns/2008reportdata.cfm.

U.S. Environmental Protection Agency (1998) National Strategy for the Development of Regional Nutrient Criteria; EPA-822/R-98-002; U.S. Environmental Protection Agency: Washington, D.C.

U.S. Environmental Protection Agency (2007) Opportunities for, and Benefits of, Combined Heat and Power at Wastewater Treatment Facilities. Eastern Research Group and Energy and Environmental
Analysis; EPA-430/R-07-003; U.S. Environmental Protection Agency: Washington, D.C.

Wang, B.; Lan, C. Q. (2011) Biomass Production and Nitrogen and Phosphorus Removal by the Green Alga Neochloris Oleoabundans in Simulated Wastewater and Secondary Municipal Wastewater Effluent. Bioresour. Technol., 102, 5639-5644.

Wijffels, R. H.; Barbosa, M. J. (2010) An Outlook on Microalgal Biofuels. Science, 329, 796-799.

Wiley, P. E.; Campbell, J. E.; McKuin, B. (2011) Production of Biodiesel and Biogas from Algae: A Review of Process Train Options. Water Environ. Res., 83, 326-338.

Worrell, E.; Phylipsen, D.; Einstein, D.; Martin, N. (2000) Energy Use and Energy Intensity of the U.S. Chemical Industry; LBNL-44314; Ernest Orlando Lawrence Berkeley National Laboratory, University of California: Berkeley, California.

Wu, H.; Fu, Q.; Giles, R.; Bartle, J. (2007) Production of Mallee Biomass in Western Australia: Energy Balance Analysis Energy \& Fuels, 22, 190-198.

Yahi, H.; Elmaleh, S.; Coma, J. (1994) Algal Flocculation-Sedimentation by pH Increase in a Continuous Reactor. Water Sci. Technol., 30, 259-267.

Yang, J.; Xu, M.; Zhang, X.; Hu, Q.; Sommerfeld, M.; Chen, Y. (2010) LifeCycle Analysis on Biodiesel Production from Microalgae: Water Footprint and Nutrients Balance. Bioresour. Technol., 102, 159-165.

Zhou, W.; Li, Y.; Min, M.; Hu, B.; Chen, P.; Ruan, R. (2011) Local Bioprospecting for High-Lipid Producing Microalgal Strains to be Grown on Concentrated Municipal Wastewater for Biofuel Production. Bioresour. Technol., 102, 6909-6919. 